\title{
Diseño de una malla de muestreo oceanográfico para el Santuario de Flora y Fauna Malpelo, Pacífico de Colombia
}

\section{Design of an oceanographic sampling network for the Malpelo Fauna and Flora Sanctuary, Pacific of Colombia}

\author{
Julio César Herrera Carmona ${ }^{l}$, Andrés Cuéllar Chacón ${ }^{l, 2}$ y Alan Giraldo López ${ }^{l}$ \\ $\begin{array}{lll}\text { (iD) } 0000-0003-0446-3275 & \text { (iD) } 0000-0002-3861-3668 & \text { (iD) } 0000-0001-9182-888 \mathrm{X}\end{array}$ \\ 1. Grupo de Investigación en Ciencias Oceanográficas, Departamento de Biología, Universidad del Valle, Calle 13 \# 100-00, Cali, Colombia. \\ julio.cesar.herrera@correounivalle.edu.co* \\ 2. Dirección Territorial Pacifico, Parques Nacionales Naturales de Colombia, Calle 29 Norte No. 6N-43, Cali, Colombia \\ * Autor de correspondencia.
}

\section{RESUMEN}

$\mathrm{C}$ on el objetivo de generar insumos para el manejo del Santuario de Flora y Fauna Malpelo, la Dirección Territorial Pacífico de Parques Nacionales Naturales de Colombia, inició en 2006 un monitoreo de condiciones oceanográficas en el área. En la actualidad este monitoreo cuenta con una malla de muestreo de solo seis estaciones ubicadas a $0,93 \mathrm{~km}(0,5$ millas náuticas) y $1,85 \mathrm{~km}$ (1 milla náutica) desde la isla, por lo que es poco eficiente debido a la reducida distancia entre estaciones e insuficiente dada la gran extensión del Santuario. Por lo tanto, se diseñó una malla de muestreo con base en datos de temperatura superficial del mar (TSM) tomados in situ, derivados del sensor remoto MODIS-Aqua. Se analizó la estructura de autocorrelación espacial a través de una función de semivarianza. La decisión para elegir la mejor malla de muestreo entre los diferentes tamaños, fue basada en la disimilitud entre estaciones asociada al modelo de semivarianza, en la varianza del error de predicción, en el patrón de corrientes marinas predominante durante el ciclo anual, y en aspectos logísticos relacionados con las limitantes de desplazamiento de las embarcaciones que realizan los monitoreos oceanográficos en el SFF Malpelo. Como resultado de considerar estas variables, se obtuvo una malla de muestreo con estaciones cada 7,41 km (4 millas náuticas) compuesta por ocho estaciones nuevas y las seis de la malla de muestreo histórica.

PALABRAS CLAVE: Santuario de Fauna y Flora Malpelo, Oceanografía, Red de muestreo, Geoestadística.

\section{ABSTRACT}

I $\mathrm{n}$ order to generate inputs for the management of the Sanctuary, the Pacific Territorial Directorate of National Natural Parks began in 2006 a monitoring of oceanographic conditions in the area. Currently, this monitoring has a sampling network of only six stations located $0.93 \mathrm{~km}(0.5 \mathrm{~nm})$ and $1.85 \mathrm{~km}(1 \mathrm{~nm})$ from the island, so it is not efficient due to the reduced distance between stations, and insufficient given the large extension of the Sanctuary. Therefore, a sampling network was designed based on Sea Surface Temperature (TSM) data taken in situ and derived from the Modis-Aqua remote sensor. The spatial autocorrelation structure was analyzed through a semi-variance function. The decision to choose the best sampling network among the different sizes was based on the dissimilarity between stations associated with the semi-variance model, on the variance of the prediction error, on the predominant pattern of marine currents during the annual cycle, and on aspects logistics related to the movement limitations of the vessels that carry out oceanographic monitoring in the SFF Malpelo. As a result of considering these variables, a sampling network was obtained with stations every $7.41 \mathrm{~km}(4 \mathrm{~nm})$, composed of eight new stations and six of the historical sampling network.

KEYWORDS: Malpelo Fauna and Flora Sanctuary, Oceanography, Sampling network, Geostatistics.

DOI: https://doi.org/10.25268/bimc.invemar.2021.50.2.1089 Publicado por INVEMAR 


\section{INTRODUCCIÓN}

Isla Malpelo y su área marina circundante albergan una gran riqueza de especies que ha permitido que sea reconocida a nivel mundial como una localidad "hot spot" de biodiversidad. Debido a esto, en 1995 el gobierno nacional reservó, alinderó y declaró la isla Malpelo como un área protegida en la categoría de Santuario de Fauna y Flora (SFF) (Ministerio del Medio Ambiente, 1995), integrándose al Sistema de Parques Nacionales Naturales de Colombia. Desde su declaratoria, el área protegida ha tenido cuatro ampliaciones (1996, 2002, 2005 y 2017). En la actualidad su área es de 2667908 ha (Ministerio de Ambiente y Desarrollo Sostenible, 2017), de las cuales solamente 63,3 ha corresponden al área emergida (isla Malpelo y 12 islotes).

Debido a su posición en la región central de la Ensenada de Panamá (EP) las aguas del SFF Malpelo tienen una gran importancia desde el punto de vista oceanográfico, ya que se ubican en un área de confluencia entre las aguas frías del sur y las aguas cálidas del norte de la ensenada. El Santuario abarca una gran parte de la dorsal de Malpelo, la cual es una estructura geomorfológica con una gran complejidad biofísica donde ocurren procesos y fenómenos de gran significancia, que le han merecido ser identificada como un Área Marina de Importancia Ecológica o Biológica (EBSA, por sus siglas en inglés). Por su parte, la EP es una zona de gran interés debido a que marca el límite oriental de las aguas de la Contracorriente Ecuatorial, y porque presenta una fuerte variabilidad interanual asociada al El Niño Oscilación del Sur (ENOS) (Fiedler y Talley, 2006). Por su posición en la concavidad ecuatorial de baja presión, la EP está fuertemente influenciada por la Zona de Convergencia Intertropical (ZCIT), ya que esta modula el ciclo anual de las condiciones oceanográficas e hidroclimatológicas de la región (Forsbergh, 1969), y genera procesos de mesoescala que a su vez influyen de manera directa en la climatología de la EP y del SFF Malpelo, como el chorro de vientos del jet de Panamá (Chelton et al., 2000; Amador et al., 2006; Rodríguez-Rubio y Giraldo, 2011). Como resultado de este proceso, un evento de surgencia estacional ocurre entre diciembre y marzo en el golfo de Panamá y la porción central de la EP, donde se ubica el SFF Malpelo, lo que genera una disminución de la Temperatura Superficial del Mar (TSM) y un aumento en la concentración de clorofila-a (Chl-a) (Legeckis, 1986; Rodríguez-Rubio y Stuardo, 2002). El Santuario presenta durante este período registros de TSM con valores en superficie de 26,0 a $27,5{ }^{\circ} \mathrm{C}$ y salinidades de 32,0 a 33,0 (Rodríguez-Rubio et al., 2007).

\section{INTRODUCTION}

Malpelo Island and its surrounding marine area are home to a great species richness, leading to its worldwide recognition as a biodiversity "hotspot". Because of this, in 1995 the Colombian government reserved, delimited, and declared Malpelo Island a protected area, with the category of Fauna and Flora Sanctuary (FFS) (Ministry of the Environment, 1995), integrating it into Colombia's National Natural Park System. Since its declaration, the protected area has been extended four times (1996, 2002, 2005, and 2017). Currently, it has an area of 2,667,908 ha (Ministry of Environment and Sustainable Development, 2017), of which only 63.3 ha correspond to the emerged area (Malpelo Island and 12 islets).

Due to its location in the central part of the Panama Bight (PB), the waters of the Malpelo FFS are of great importance from an oceanographic point of view, since they are located in an area of confluence between the cold waters of the south of the PB and the warm waters of the north of the PB. The Sanctuary covers a considerable part of the Malpelo Ridge, a geomorphological structure of great biophysical complexity along which processes and phenomena of great significance occur, justifying its identification as an Ecologically or Biologically Significant Marine Area (EBSA). The PB is an area of considerable interest because it marks the eastern limit of the waters of the Equatorial Counter Current, and because it displays strong interannual variability associated with the El Niño Southern Oscillation (ENSO) (Fiedler and Talley, 2006). Due to its position in the low-pressure equatorial concavity, the PB is strongly influenced by the Intertropical Convergence Zone (ITCZ), since this modulates the annual cycle of oceanographic and hydroclimatic conditions in the region (Forsbergh, 1969) and generates mesoscale processes that in turn directly influence the climate of the PB and of the Malpelo FFS, such as the winds of the Panama jet (Chelton et al., 2000; Amador et al., 2006; Rodríguez-Rubio and Giraldo, 2011). As a result, a seasonal upwelling event occurs between December and March in the Gulf of Panama and the central portion of the $\mathrm{PB}$, where the Malpelo FFS is located, which generates a decrease in Sea Surface Temperature (SST) and an increase in chlorophyll-a (Chl-a) concentrations (Legeckis, 1986; Rodríguez-Rubio and Stuardo, 2002). During this period, SST values of 26.0 to $27.5^{\circ} \mathrm{C}$ are recorded for the sanctuary, alongside salinities between 32.0 to 33.0 (Rodríguez-Rubio et al., 2007). However, towards the western margin of the Malpelo FFS, SST values above $27.5^{\circ} \mathrm{C}$ and salinities of 
No obstante, hacia el margen occidental del SFF Malpelo se observan valores de TSM por encima de los $27,5^{\circ} \mathrm{C}$ y salinidades de 32,0 y 32,8 (CCO y DIMAR, 2019). El resto del año, el campo de vientos es dominado por los vientos alisios del sur lo que limita el desarrollo de la surgencia oceánica (Kessler, 2006). Durante el segundo semestre del año, la TSM presenta un gradiente de cambio menor al observado en el período enero-abril, con un predominio de registros de TSM de 27,0 a $27,2{ }^{\circ} \mathrm{C}$ y salinidades entre 32,0 y 32,2 (CCO y DIMAR, 2019).

Con el fin de generar insumos para el manejo del Santuario, la Dirección Territorial Pacífico (DTPA) de Parques Nacionales Naturales (PNN), inició en 2006 un monitoreo de condiciones oceanográficas, el cual ha sido apoyado por la Universidad del Valle desde 2012. Este monitoreo se ha llevado a cabo ininterrumpidamente hasta la actualidad (2021), con excepción de 2018, para un total de 15 años de muestreo. La malla de muestreo utilizada actualmente está constituida por seis estaciones localizadas a $0,93 \mathrm{~km}$ ( 0,5 millas náuticas) y $1,85 \mathrm{~km}$ (1 milla náutica) desde la isla. Se presume que este diseño es poco eficiente debido a la reducida distancia que hay entre estaciones y es insuficiente dada la gran extensión del Santuario $\left(26679 \mathrm{~km}^{2}\right.$ ). El vértice noroccidental, en límites con el Distrito Nacional de Manejo Integrado (DNMI) Yuruparí Malpelo, se encuentra a 124,08 km (67 millas náuticas) desde la isla, mientras que el límite nororiental, que es el más alejado, se encuentra a 172,24 km (93 millas náuticas) desde la isla. Dada la necesidad actual de reformular la malla de muestreo oceanográfico, de manera que provea la mejor información posible y que sea costo-efectiva, el objetivo de este trabajo es diseñar una malla de muestreo óptima a partir del análisis de la estructura de autocorrelación espacial de la TSM en el SFF Malpelo, utilizando análisis geoestadísticos para datos in situ y derivados de sensores remotos.

\section{MATERIALES Y MÉTODOS}

Área de estudio

El SFF Malpelo está ubicado en la región central de la cuenca pacífica colombiana (CPC) (Figura 1), la cual se enmarca en la ensenada de Panamá (EP), y esta a su vez en el Pacífico Oriental Tropical (POT). En el centro del Santuario, se encuentra isla Malpelo, la cual es la porción de tierra más occidental de Colombia en el Pacífico, separada del territorio continental por más de $380 \mathrm{~km}, \mathrm{y}$ ubicada aproximadamente a $505 \mathrm{~km}$ al occidente del puerto
32.0 and 32.8 are observed (CCO and Dimar, 2019). During the rest of the year the wind field is dominated by southerly trade winds that limit the development of oceanic upwelling (Kessler, 2006). During the second half of the year, SST presents a smaller gradient of change than that observed during the January-April period, where the majority of SST values are between 27.0 to $27.2^{\circ} \mathrm{C}$ and salinities fall between 32.0 and 32.2 (CCO and DIMAR, 2019).

In order to produce inputs that would help it manage the sanctuary, the Pacific Territorial Direction (DTPA in spanish), initiated a process to monitor oceanographic conditions in the area in 2006. This work has been supported by the Universidad del Valle since 2012. Monitoring has been carried out continuously from that date until the present year (2021), with the exception of 2018, resulting in a total of 15 years of sampling. The sampling network currently used consists of six stations located $0.93 \mathrm{~km}(0.5$ nautical miles) and $1.85 \mathrm{~km}$ (1 nautical mile) from the island. This design is presumed to be inefficient, due to the small distances between stations, and insufficient, given the large size of the sanctuary $\left(26,679 \mathrm{~km}^{2}\right)$. The northwestern vertex, which limits with the Yurupari Malpelo National Integrated Management District (DNMI), is $124.08 \mathrm{~km}$ (67 nautical miles) from the island, while the northeastern limit, the most distant, is $172.24 \mathrm{~km}$ (93 nautical miles) away. Given the current need to reformulate the oceanographic sampling network to ensure it is capable of providing the best possible information and is cost-effective, the objective of this paper is to design an optimal sampling network based on an analysis of the spatial autocorrelation structure of SSTs in the Malpelo FFS, using geostatistical analysis for data gathered in situ and from remote sensors.

\section{MATERIALS AND METHODS}

\section{Study area}

The Malpelo FFS is located in the central section of the Colombian Pacific Basin (CPB) (Figure 1), itself contained within the Panama Bight (PB), which in turn forms part of the Eastern Tropical Pacific (ETP). Malpelo Island is located in the center of the sanctuary, which itself occupies the westernmost portion of Colombia's land territory in the Pacific. It is separated from the continental territory by more than $380 \mathrm{~km}$ and located approximately $505 \mathrm{~km}$ west of the port of Buenaventura (Department of Valle del Cauca, Colombia) of which it forms a part. The island is elongated in shape, with a length of about 1,643 
de Buenaventura (Valle del Cauca). En la división político administrativa, pertenece al municipio de Buenaventura, Colombia. La forma de la isla es alargada y presenta cerca de $1643 \mathrm{~m}$ de longitud, un ancho variable que alcanza los $727 \mathrm{~m}$ y una altura máxima de $300 \mathrm{~m}$. En los alrededores de la isla es posible encontrar 12 islotes. Él área emergida de las islas (Malpelo y los islotes) es cerca de $0,633 \mathrm{~km}^{2}$. Sin embargo, si se considera una superficie tridimensional el área es alrededor de 1,215 km² (López-Victoria y Rozo, 2006) $\mathrm{m}$; it is of variable width (maximum $727 \mathrm{~m}$ ) and reaches a height of $300 \mathrm{~m}$. There are 12 islets in the surrounding waters. The emerged portion of the islands (Malpelo and the islets) has an area of about $0.633 \mathrm{~km}^{2}$. However, its threedimensional surface is about $1,215 \mathrm{~km}^{2}$ (López-Victoria and Rozo, 2006).

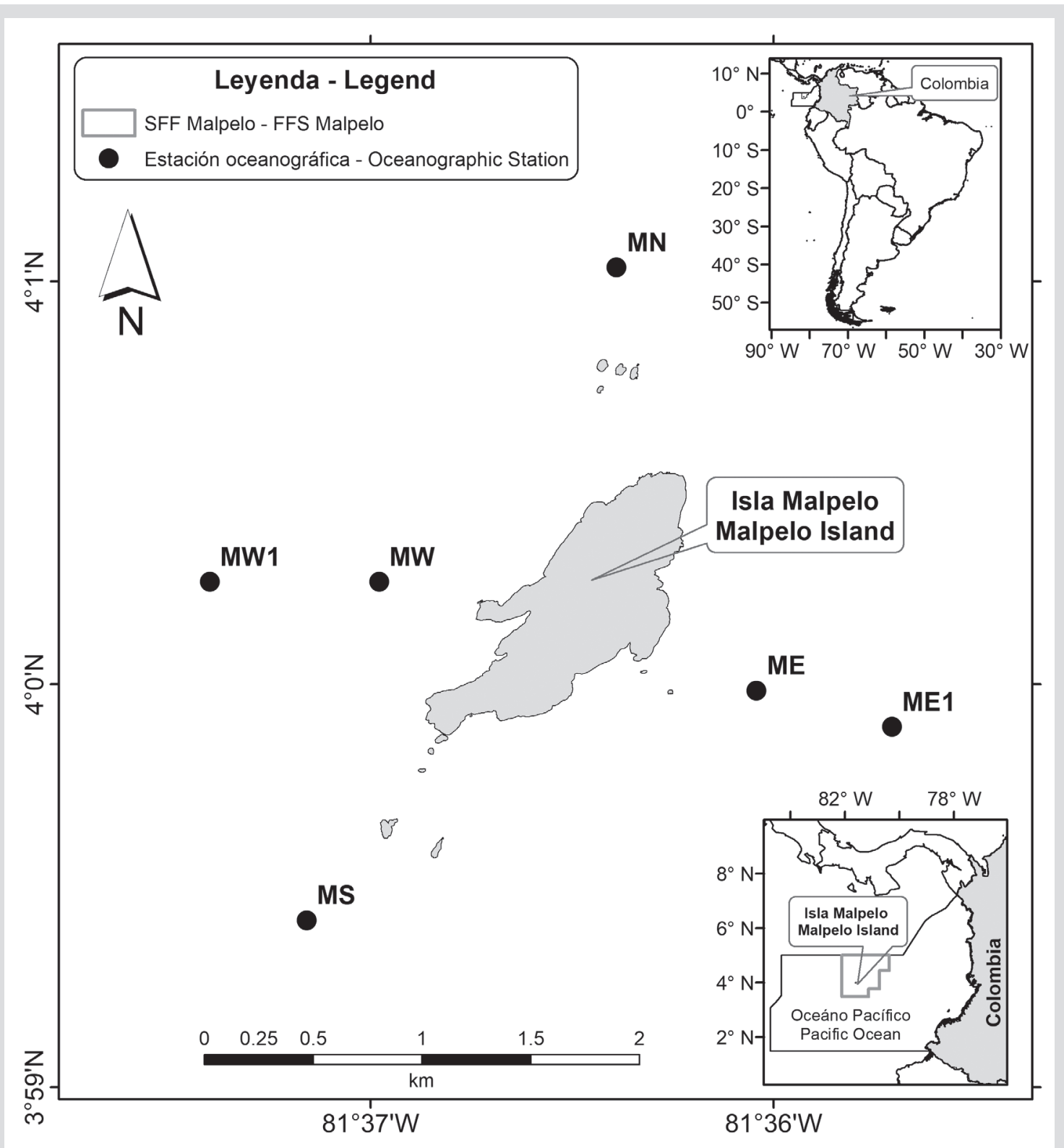

Figura 1. Ubicación geográfica de la zona de estudio y de la malla de muestreo actual para el monitoreo oceanográfico del Santuario de Fauna y Flora Malpelo.
Figure 1. Geographic location of the study area and the current sampling network for oceanographic monitoring of the Malpelo Flora and Fauna Sanctuary. 


\section{Conjuntos de datos}

Para el análisis de variabilidad espacial de la TSM del SFF Malpelo se usaron dos conjuntos de datos: uno obtenido in situ y otro derivado del sensor MODIS-Aqua (Moderate Resolution Imaging Spectroradiometer-Aqua). La temperatura superficial es una variable que ha sido usada en el diseño de redes de muestreo como la que propusieron Giraldo et al. (2001) para el estuario de la Ciénaga Grande de Santa Marta. Además de ajustarse fácilmente a un modelo de semivarianza, en ese mismo estudio la temperatura mostró ser una variable costo eficiente y por lo tanto idónea para formular redes de muestreo mediante análisis geoestadísticos de autocorrelación espacial. Los datos obtenidos in situ, corresponden al monitoreo oceanográfico de la Dirección Territorial Pacífico (DTPA) de Parques Nacionales Naturales (PNN) realizado entre 2012 y 2019 con apoyo de la Universidad del Valle. En este período de tiempo, se han realizado trece muestreos con una periodicidad de entre uno y tres muestreos en el. Esta malla está constituida por seis estaciones ubicadas alrededor de la isla a $0,5 \mathrm{mn}$ y $1 \mathrm{mn}$ (Figura 1). El segundo conjunto de datos fue obtenido del producto MODIS SST v2019 el cual es derivado del sensor MODIS-Aqua (Werdell et al., 2013). El período de tiempo empleado fue julio de 2002-julio de 2019 (205 meses/17,1 años). Las imágenes usadas fueron globales, con un nivel de procesamiento L3, tomadas por el sensor durante el día, con una resolución temporal mensual, y con una resolución espacial de $4 \mathrm{~km}$. Se usó la TSM derivada de las bandas térmicas infrarrojas de onda larga a $11 \mu \mathrm{m}$ y $12 \mu \mathrm{m}$ (bandas 31 y 32 ). Estos conjuntos de datos son distribuidos por el Physical Oceanography Distributed Active Archive Center (PO.DAAC) (https://podaac.jpl.nasa. gov). Para cada mes, se extrajo la información del polígono del SFF Malpelo.

\section{Análisis estadístico}

Cuando se cuenta con múltiples variables regionalizadas (en este caso la TSM in situ y de sensores remotos) una alternativa para abordar el problema multivariado es utilizar un Análisis de Componentes Principales (ACP) (Giraldo, 2002). Esta técnica es ampliamente usada para particionar la varianza de un conjunto de series de tiempo espacialmente distribuidas en unos pocos modos estadísticos o Componentes Principales (CP), que no están correlacionados. El ACP, comprende el cálculo de las Funciones Empíricas Ortogonales (FEO), las cuales se pueden describir como un conjunto de vectores que maximizan la varianza de las variables empleadas y
Data sets

Two data sets were used for the spatial variability analysis of SST in the Malpelo FFS: one obtained in situ and the other derived from a MODIS-Aqua (Moderate Resolution Imaging Spectroradiometer-Aqua) sensor. Surface temperature is a variable that has been used in the design of sampling networks such as the one proposed by Giraldo et al. (2001) for the estuary of the "Ciénaga Grande de Santa Marta", Colombia. Further, to demonstrating that the technique fitted a semivariance model easily, this study showed temperature to be a cost-efficient variable and therefore suitable for formulating sampling networks using geostatistical analysis of spatial autocorrelation. The data obtained in situ corresponded to the oceanographic monitoring carried out by the DTPA between 2012 and 2019 with support from the Universidad del Valle. During this period, thirteen sampling were carried out with a periodicity of between one and three samplings each year. The network sampling employed consists of six stations located around the island at distances of between $0.93 \mathrm{~km}(0.5 \mathrm{~nm})$ and $1.83 \mathrm{~km}(1 \mathrm{~nm})$ (Figure 1). The second dataset was obtained using the MODIS SST v2019 product, derived from the MODIS-Aqua sensor (Werdell et al., 2013). The time period used was July 2002-July 2019 (205 months/17.1 years). The images used were global, with a processing level L3, taken by the sensor during the day, with a monthly temporal resolution and a spatial resolution of $4 \mathrm{~km}$. SST data derived from longwave infrared thermal bands at $11 \mu \mathrm{m}$ and 12 $\mu \mathrm{m}$ (bands 31 and 32) were employed. These data sets are distributed by the Physical Oceanography Distributed Active Archive Center (PO.DAAC) (https://podaac.jpl. nasa.gov). Information was extracted from the Malpelo FFS polygon for each month.

\section{Statistical analysis}

When multiple regionalized variables are available (in this case in situ and remotely sensed SST) an alternative way to address the multivariate problem is to use a Principal Component Analysis (PCA) (Giraldo, 2002). This technique is widely used to partition the variance of a set of spatially distributed time series into a few uncorrelated statistical modes, or Principal Components (PC). PCA involves the calculation of Empirical Orthogonal Functions (EOF), which may be described as a set of vectors that maximize the variance of the variables used and constitute the orthogonal basis of a set of time series at different measurement sites. After generating the principal axes in the traditional way, following Manly and Navarro (2016), these were then 
constituyen la base ortogonal de un conjunto de series de tiempo en distintos sitios de medición. Después de generar los ejes principales de la forma tradicional de acuerdo a Manly y Navarro (2016), posteriormente se realiza la correspondiente interpretación de estos nuevos ejes en términos de la variabilidad explicada por cada componente respecto a cada variable original y finalmente se lleva a cabo un análisis geoestadístico a través de la estimación de la función de semivarianza y de la aplicación de algún procedimiento Kriging con base en los datos de los ejes generados (Giraldo, 2002).

Para el muestreo in situ, las unidades de muestreo del ACP fueron las estaciones de la malla de monitoreo oceanográfico del SFF Malpelo (seis estaciones) y las variables fueron los muestreos realizados (13). Para el análisis de la TSM de los sensores remotos, las unidades de muestreo fueron los píxeles de cada imagen de TSM del SFF Malpelo (1284), y las variables los meses de toda la serie julio 2002-julio 2019. Para derivar los vectores propios (eigenvectors) y los valores propios (eigenvalues) se usó la matriz de correlación (Emery y Thompson, 2014). El análisis numérico para los datos in situ fue realizado en el programa Statistica v7.0 (Statsoft, 2007) y el análisis para los datos de sensores remotos fue basado en imágenes y realizado bajo la herramienta "Principal Components" del programa ArcGis 10.5. Posteriormente, usando el componente de máxima varianza (Componente Principal 1), se realizaron los análisis geoestadísticos.

Una de las aplicaciones importantes del estudio de información georreferenciada mediante análisis geoestadísticos es el diseño de redes de muestreo (Cressie, 1989). La primera etapa en el desarrollo de un análisis geoestadístico es la determinación de la dependencia espacial entre los datos medidos de una variable. Para llevarla a cabo se pueden usar tres funciones: el semivariograma, el covariograma y el correlograma (Giraldo, 2002). Entre estas, la única función que no requiere hacer estimación de parámetros es la función de semivarianza o disimilaridad, por lo que para analizar la estructura de correlación espacial de la TSM en el SFF Malpelo se empleó el semivariograma.

La función de semivarianza caracteriza las propiedades de dependencia espacial del proceso evaluado. Esta función se calcula para varias distancias $h$. Para interpretar el semivariograma experimental se parte del criterio de que a menor distancia entre los sitios, mayor similitud o correlación espacial entre las observaciones. Por ello, en presencia de autocorrelación se espera que para interpreted in terms of the variability explained by each component with respect to each original variable; finally, a geostatistical analysis was carried out by estimating the semivariance function and applying a Kriging procedure using the data taken from the axes generated (Giraldo, 2002).

For the in situ sampling, the PCA sampling units used were the stations of the Malpelo FFS oceanographic monitoring network (six stations) and the variables were the sampling performed (13). The sampling units used for the remote sensing SST analysis were the pixels in each SST image of the Malpelo FFS (1284), while the variables were the months of the entire series (July 2002-July 2019). A correlation matrix (Emery and Thompson, 2014) was used to derive the eigenvectors and eigenvalues. The numerical analysis of the in situ data was performed using the Statistica v7.0 program (Statsoft, 2007) and the analysis of the remotely sensed data was based on imagery and performed using the "Principal Components" tool contained in the ArcGis 10.5 software. Subsequently, geostatistical analyses were performed using the maximum variance component (Principal Component 1, or PC1).

One of the important applications of the study of georeferenced information using geostatistical analysis is the design of sampling networks (Cressie, 1989). The first stage in the development of a geostatistical analysis is the determination of the spatial dependence between the measured data of a variable. Three functions may be used to carry this out: the semivariogram, covariogram and correlogram (Giraldo, 2002). Of these, the only function that does not require parameter estimation is the semivariogram or dissimilarity function, and it was therefore chosen to analyze the spatial correlation structure of SST in the Malpelo FFS.

The semivariance function characterizes the spatial dependence properties of the process being evaluated. This function is calculated for various distances, $h$. To interpret the experimental semivariogram, it is assumed that the smaller the distance between sites, the greater the spatial similarity or correlation between observations. Therefore, in the presence of autocorrelation, it is expected that for small values of $h$ the experimental semivariogram will have smaller magnitudes than those it takes when the distances $h$ increase. Since the experimental semivariogram is calculated only for some average discrete distances, it is necessary to fit models that generalize the observed experimental semivariogram to any distance. In general such models can 
valores de $h$ pequeños el semivariograma experimental tenga magnitudes menores a las que esta toma cuando las distancias $h$ se incrementan. Como el semivariograma experimental es calculado solo para algunas distancias discretas promedio, es necesario hacer el ajuste de modelos que generalicen lo observado en el semivariograma experimental a cualquier distancia. En general dichos modelos pueden dividirse en no acotados (lineal, logarítmico, potencial) y acotados (esférico, exponencial, gaussiano) (Warrick et al., 1986). Los del segundo grupo garantizan que la covarianza de los incrementos es finita, por lo cual son ampliamente usados cuando hay evidencia de que presentan buen ajuste. De acuerdo con Giraldo (2002), estos modelos tienen tres parámetros comunes (Figura 2) que son descritos a continuación:

Efecto Pepita: Se denota por $\mathrm{C}_{0}$ y representa una discontinuidad puntual del semivariograma en el origen (Figura 2). Puede ser debido a errores de medición en la variable o a la escala de la misma. En algunas ocasiones puede ser indicativo de que parte de la estructura espacial se concentra a distancias inferiores a las observadas. be divided into unbounded (linear, logarithmic, potential) and bounded (spherical, exponential, Gaussian) (Warrick et al., 1986). Models belonging to the second group ensure that the covariance of the increments is finite, so they are widely used when there is evidence of good fit. According to Giraldo (2002), these models have three common parameters (Figure 2), which are described below:

Nugget effect: The Nugget effect is denoted by $\mathrm{C}_{0}$ and represents a point discontinuity of the semivariogram at origin (Figure 2). It may be the result of measurement errors in the variable or to its scale. Sometimes it may be indicative that part of the spatial structure is concentrated at distances below those observed.

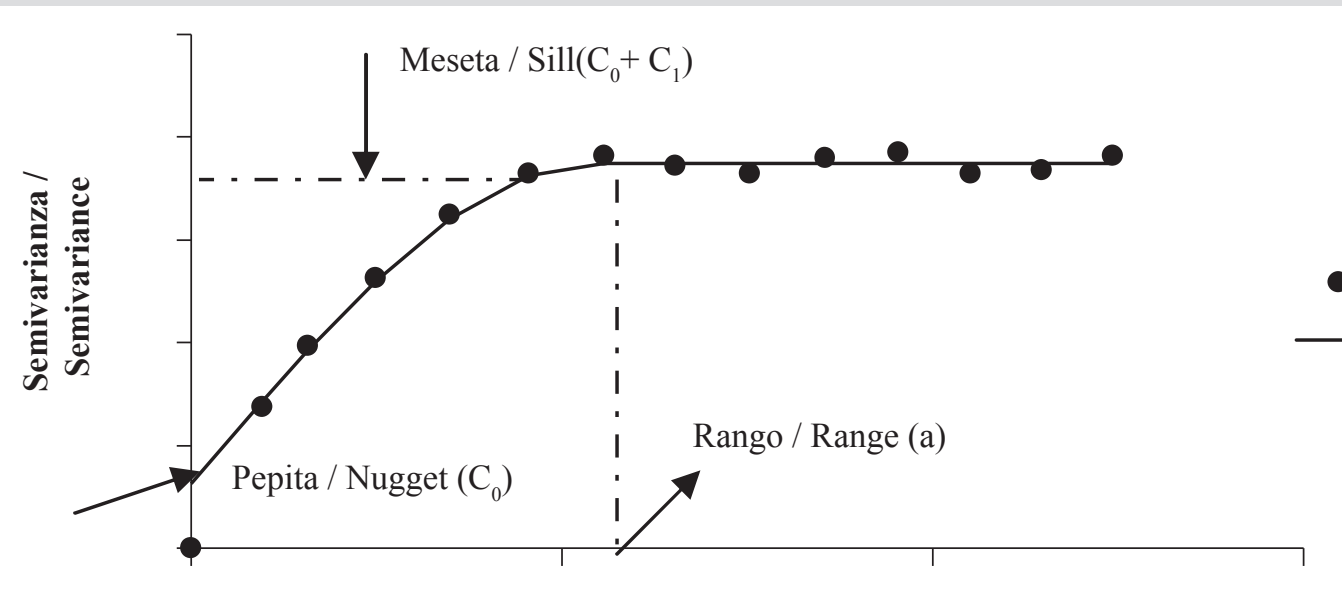

Distancia / Distance

Figura 2. Comportamiento típico de un semivariograma acotado con una representación de los parámetros básicos. SEMEXP corresponde al semivariograma experimental y MODELO al ajuste de un modelo teórico (Tomado de Giraldo, 2002).
Figure 2. Typical behavior of a bounded semivariogram with a representation of the basic parameters. SEMEXP corresponds to the experimental semivariogram and MODEL to the fit of a theoretical model (Taken from Giraldo, 2002).
Meseta: Es la cota superior del semivariograma. También puede definirse como el límite del semivariograma cuando la distancia $h$ tiende a infinito y ya no hay correlación espacial entre los puntos de muestreo. La meseta puede ser o no finita. Los semivariogramas que tienen meseta finita cumplen con la hipótesis de estacionariedad fuerte; mientras
Plateau: The Plateau is the upper limit of the semivariogram. It may also be defined as the limit of the semivariogram when the distance $h$ tends to infinity and there is no further spatial correlation between the sampling points. The plateau may or may not be finite. Semivariograms with finite plateaux comply with the strong stationarity 
que cuando ocurre lo contrario, el semivariograma define un fenómeno natural que cumple sólo con la hipótesis intrínseca. La meseta se denota por $\mathrm{C}_{1}$ o por $\left(\mathrm{C}_{0}+\mathrm{C}_{1}\right)$ cuando la pepita es diferente de cero.

Rango: En términos prácticos, corresponde a la distancia a partir de la cual dos observaciones son independientes y no están autocorrelacionadas espacialmente. El rango se interpreta como la zona de influencia. Existen algunos modelos de semivariograma en los que no existe una distancia finita para la cual dos observaciones sean independientes. Por esto, se llama rango efectivo a la distancia para la cual el semivariograma alcanza $95 \%$ de la meseta. Entre más pequeño sea el rango, más cerca se está del modelo de independencia espacial.

Para analizar la estructura de autocorrelación espacial mediante el semivariograma, se usó el primer componente principal (CP1), debido a que este es el de mayor varianza y el que captura la mayor variabilidad temporal del conjunto de datos. El ajuste de modelos del CP1 de la TSM in situ y derivada de sensores remotos del SFF Malpelo, fue realizado a través de la estimación de mínimos cuadrados ordinales y ponderados, y los modelos empleados fueron: exponencial, gausiano y esférico. Previo a esto se verificó si la correlación presentaba direccionalidad (isotropía o anisotropía). El análisis de la direccionalidad de la correlación, los semivariogramas experimentales y el ajuste de modelos fueron realizados con la rutina GeoR del programa R (Ribeiro y Diggie, 2018). Para seleccionar el mejor modelo se usó como criterio los cuadrados medios del error. Posteriormente, usando el mejor modelo de semivarianza se realizaron las predicciones de la variable para cada malla de muestreo mediante el método Kriging, y se calculó la varianza del error de predicción para cada tamaño de red usando la aproximación de Cressie (1993). Para un mayor detalle, Giraldo (2002) resume la teoría de la estimación de la estructura de autocorrelación espacial, el método de predicción por Kriging, y el cálculo de la varianza del error de predicción.

\section{RESULTADOS}

\section{Conjuntos de datos}

Durante el período abril 2012 y mayo 2019, la TSM promedio in situ obtenida en las aguas del SFF Malpelo fue $26,89^{\circ} \mathrm{C}$. Durante el primer trimestre del año (enero-marzo) la temperatura promedio fue $25,57^{\circ} \mathrm{C}$, en el segundo (abriljunio) $28,08^{\circ} \mathrm{C}$, en el tercer (julio-septiembre) $27,38^{\circ} \mathrm{C}$ y hypothesis. When the opposite occurs, the semivariogram defines a natural phenomenon that complies only with the intrinsic hypothesis. The plateau is denoted by $\mathrm{C}_{1}$, or by $\left(\mathrm{C}_{0}+\mathrm{C}_{1}\right)$ when the nugget is different from zero.

Range: In practical terms, Range corresponds to the distance beyond which two observations are independent and not spatially autocorrelated. The range is interpreted as the zone of influence. In some semivariogram models there is no finite distance for which two observations are independent. Therefore, the distance for which the semivariogram reaches $95 \%$ of the plateau is called the effective range. The smaller the range, the closer to the spatial independence model.

The PC1 was used to analyse the spatial autocorrelation structure using the semivariogram, since this has the highest variance and captures the greatest temporal variability of the data set. Adjustment of the PC1 models of the SST in situ and as derived from remote sensors in the Malpelo FFS, was carried out by estimating ordinal and weighted least squares. The models used were: exponential, Gaussian and spherical. Prior to this, it was verified whether the correlation presented directionality (isotropy or anisotropy). The analysis of correlation directionality, experimental semivariograms and model-fitting were performed using the GeoR routine of the $\mathrm{R}$ software (Ribeiro and Diggie, 2018). Mean squared error was used as a criterion to select the best model. Subsequently, using the best semivariance model, the predictions of the variable for each sampling network were performed using a Kriging method, and the variance of the prediction error was calculated for each network size using the approximation of Cressie (1993). For greater detail, Giraldo (2002) summarizes the theory of spatial autocorrelation structure estimation, the Kriging prediction method and the calculation of the variance of prediction error.

\section{RESULTS}

\section{Data sets}

During the period April 2012 to May 2019, the average in situ SST obtained in the waters of the Malpelo FFS was $26.89{ }^{\circ} \mathrm{C}$. During the first quarter of the year (January-March) the average temperature was $25.57{ }^{\circ} \mathrm{C}$, during the second (April-June) $28.08{ }^{\circ} \mathrm{C}$, during the third (July-September) $27.38^{\circ} \mathrm{C}$ and during the fourth (OctoberDecember) $26.07{ }^{\circ} \mathrm{C}$. During the 13 sampling conducted in the same period, the maximum SST levels were found in 
en el cuarto (octubre-diciembre) $26,07^{\circ} \mathrm{C}$. Durante los 13 muestreos realizados en el mismo período, las máximas TSM se encontraron en abril de $2012\left(28,93{ }^{\circ} \mathrm{C}\right)$ y septiembre de $2015\left(28,58^{\circ} \mathrm{C}\right)$. En el primer caso, coincidió con el fin de un período La Niña (2010-2012) y en el segundo con El Niño 2015-2016. De otro lado, la mínima TSM se observó en diciembre de $2012\left(23,97{ }^{\circ} \mathrm{C}\right)$ y marzo de $2015\left(25,11^{\circ} \mathrm{C}\right)$ (Figura 1). En el primer caso, coincidió con un período neutro y en el segundo con El Niño 2015-2016.
April $2012\left(28.93{ }^{\circ} \mathrm{C}\right)$ and in September $2015\left(28.58^{\circ} \mathrm{C}\right)$. In the first case, these temperatures coincided with the end of a La Niña period (2010-2012) and in the second with the 2015-2016 El Niño. On the other hand, the minimum SST values were observed in December $2012\left(23.97^{\circ} \mathrm{C}\right)$ and March $2015\left(25.1{ }^{\circ} \mathrm{C}\right)$ (Figure 1). In the first case, these temperatures coincided with a neutral period and in the second with El Niño 2015-2016.

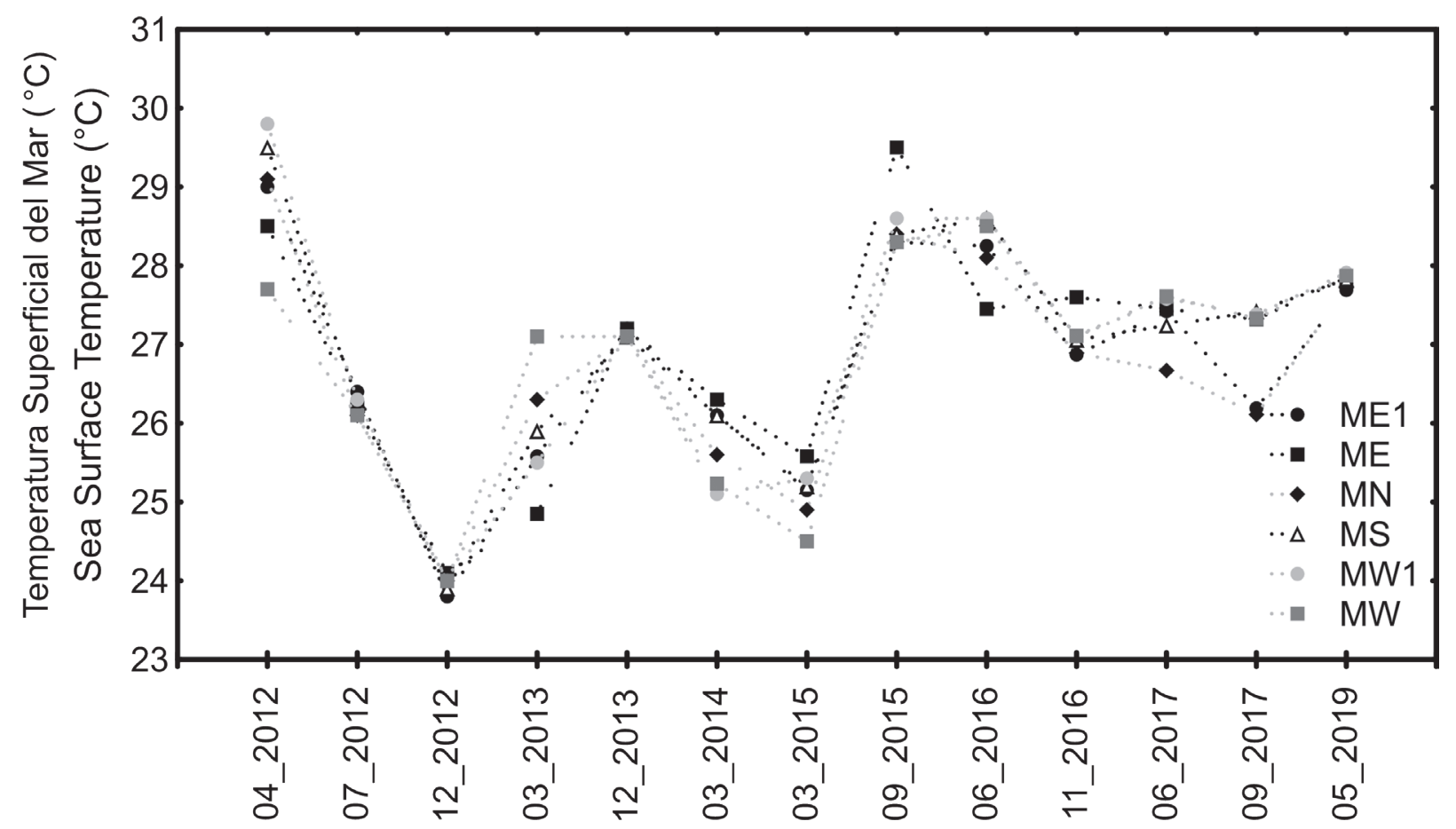

Figura 3. Temperatura superficial del mar de las estaciones de la malla de muestreo actual del Santuario de Fauna y Flora Malpelo, tomada entre abril de 2012 y mayo de 2019.
Figure 3. Sea surface temperature (SST) at the stations in the current sampling network of the Malpelo Fauna and Flora Sanctuary, recorded between April 2012 and May 2019.
El promedio de la TSM en isla Malpelo obtenida a partir del sensor Modis-Aqua (2002-2019) fue $27,1{ }^{\circ} \mathrm{C}$. Durante el primer trimestre del año (enero-marzo) la temperatura promedio fue $26,78^{\circ} \mathrm{C}$, en el segundo (abriljunio) $27,75^{\circ} \mathrm{C}$, en el tercer (julio-septiembre) $27,03^{\circ} \mathrm{C}$ y en el cuarto (octubre-diciembre) $26,89^{\circ} \mathrm{C}$. En el período 2002 2019, las máximas TSM se encontraron en mayo de 2016 $\left(30,17{ }^{\circ} \mathrm{C}\right)$ y abril de $2010\left(29,25^{\circ} \mathrm{C}\right)$. En el primer caso, coincidió con el fin de El Niño 2015-2016 y en el segundo con el fin de El Niño 2009-2010. De otro lado, las mínimas TSM se obsevaron en agosto de $2010\left(23,74{ }^{\circ} \mathrm{C}\right)$ y marzo de $2009\left(24,01^{\circ} \mathrm{C}\right)$ (Figura 2). En el primer caso, coincidió con La Niña 2010-2012 y en el segundo con La Niña 2009.
The average SST at Malpelo Island obtained using the MODIS-Aqua sensor (2002-2019) was $27.11{ }^{\circ} \mathrm{C}$. During the first quarter of the year (January-March) the average temperature was $26.78{ }^{\circ} \mathrm{C}$, in the second (April-June) $27.75{ }^{\circ} \mathrm{C}$, in the third (July-September) $27.03{ }^{\circ} \mathrm{C}$ and in the fourth (October-December) $26.89^{\circ} \mathrm{C}$. In the period 2002-2019, the maximum SSTs were found in May $2016\left(30.17^{\circ} \mathrm{C}\right)$ and April $2010\left(29.25^{\circ} \mathrm{C}\right)$. The first case coincided with the end of El Niño 2015-2016 and the second with the end of El Niño 2009-2010. On the other hand, the lowest SST were observed in August $2010\left(23.74^{\circ} \mathrm{C}\right)$ and March $2009\left(24.01^{\circ} \mathrm{C}\right.$ ) (Figure 2). In the first case, these temperatures coincided with $\mathrm{La}$ Niña 2010-2012 and in the second with La Niña 2009. For the 
Para el polígono del SFF Malpelo (línea gris en la Figura 2), durante el período 2002-2019 la TSM promedio fue $27,23^{\circ} \mathrm{C}$. Durante el primer trimestre del año (enero-marzo) la temperatura promedio fue $26,72^{\circ} \mathrm{C}$, en el segundo (abriljunio) $27,98{ }^{\circ} \mathrm{C}$, en el tercer (julio-septiembre) $27,18^{\circ} \mathrm{C}$ y en el cuarto (octubre-diciembre) $27,03^{\circ} \mathrm{C}$.
Malpelo FFS polygon (grey line in Figure 2), the average SST during the period $2002-2019$ was $27.23{ }^{\circ} \mathrm{C}$. During the first quarter of the year (January-March) the average temperature was $26.72{ }^{\circ} \mathrm{C}$, during the second quarter (April-June) $27.98^{\circ} \mathrm{C}$, during the third quarter (July-September) $27.18^{\circ} \mathrm{C}$ and during the fourth quarter (October-December) $27.03^{\circ} \mathrm{C}$.

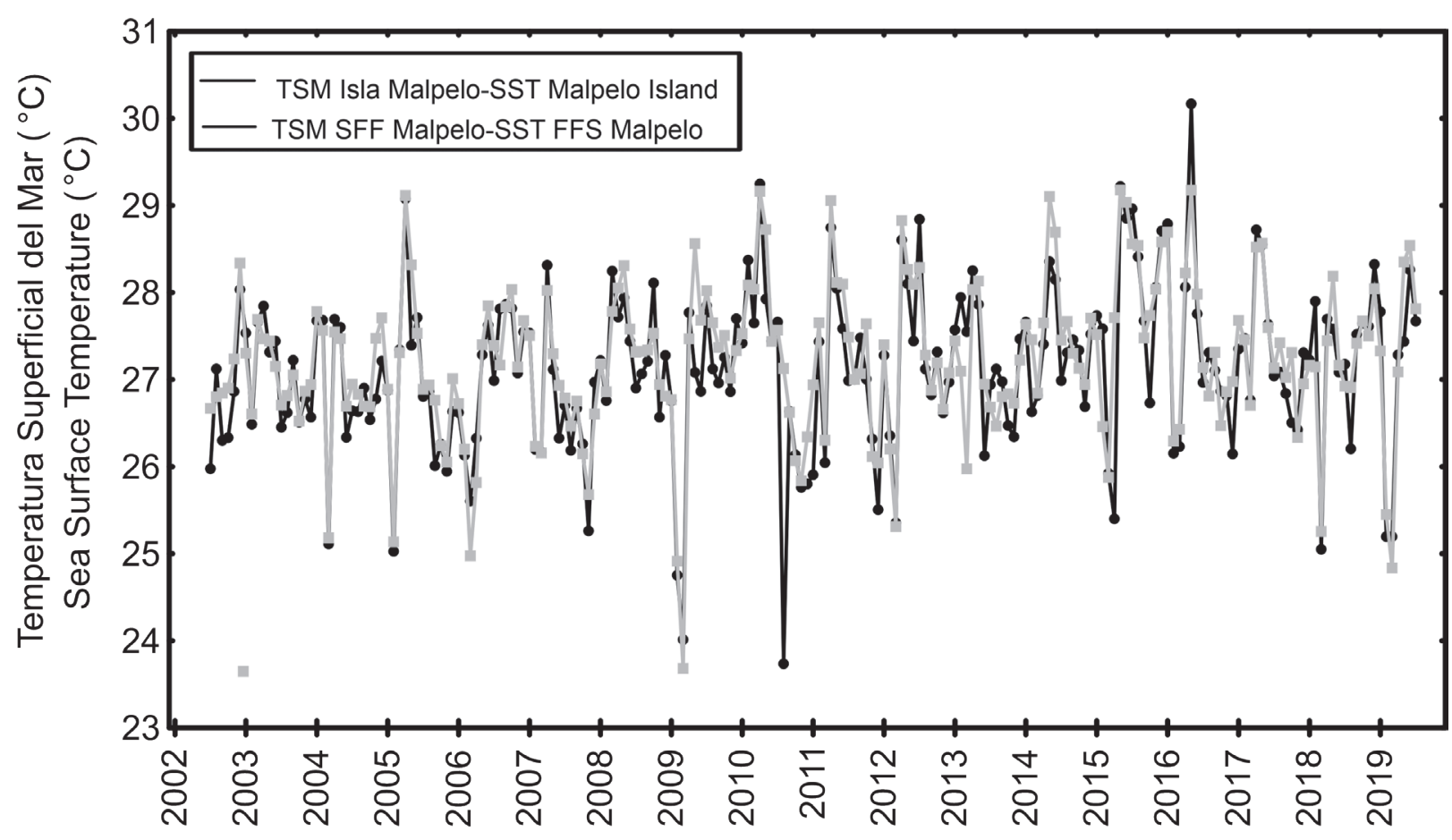

Figura 4. Temperatura superficial del mar (TSM) obtenida a partir del sensor Modis-Aqua entre julio de 2002 y julio de 2019, para isla Malpelo y para el polígono del Santuario de Fauna y Flora Malpelo.
Figure 4. Sea surface temperature (SST) between July 2002 and July 2019, for Malpelo Island and the Malpelo Flora and Fauna Sanctuary polygon, obtained using the MODIS-Aqua sensor.
En el análisis de componentes principales (ACP) de la TSM in situ, el primer componente principal (CP1) presentó un aporte a la varianza total de $88,3 \%$ con un valor propio asociado de 5,3 y el CP2 un aporte a la varianza de 5,4 \% y un valor propio de 0,3. En el análisis de la TSM derivada de sensores remotos el CP1 presentó un aporte a la varianza de $65,1 \%$ y un valor propio asociado de 21,9, y el CP2 un aporte a la varianza de $12,3 \%$ y un valor propio de 7,6. Temporalmente, el CP1 del análisis de sensores remotos describió la variabilidad del ciclo anual de la TSM en el Santuario, y espacialmente presentó una fuerte correlación con la TSM $(\mathrm{r}=0,86 ; \mathrm{p}>0,05)$ (Figura 3). La zona noroccidente presentó valores extremos estandarizados por encima del promedio, mientras que en el suroriente los valores se ubicaron por debajo del promedio (Figura 3). En los dos casos (datos in situ y de sensores
In the PCA of in situ SST, the PC1 made a contribution to the total variance of $88.3 \%$, with an associated eigenvalue of 5.3 , while the PC2 contributed $5.4 \%$, with an eigenvalue of 0.3 . In the analysis of SST derived from remote sensing, the PC1 contributed $65.1 \%$ to variance with an associated eigenvalue of 21.9 , and the $\mathrm{PC} 2$ a contribution of $12.3 \%$ and an eigenvalue of 7.6. In terms of time, the $\mathrm{PC} 1$ of the remote sensing analysis described the variability of the annual cycle of SST in the sanctuary and, spatially speaking, presented a strong correlation with $\operatorname{SST}(r=0.86 ; p>0.05)$ (Figure 3$)$. The north-western zone presented extreme above-average standardized values, while in the southeast the values were below average (Figure 3). In both cases (in situ and remote sensing of data), the first component accounted for a high percentage of the temporal variability, so a semivariance model was only adjusted to 
remotos), el primer componente reunió un alto porcentaje de la variabilidad temporal por lo que se ajustó un modelo de semivarianza solo para el primer componente. El cálculo de la semivarianza en diferentes direcciones mostró que estas tienen formas similares, por lo que se consideró que el fenómeno es isotrópico. the first component. The calculation of the semivariance in different directions showed them to have similar shapes, so the phenomenon was considered to be isotropic.

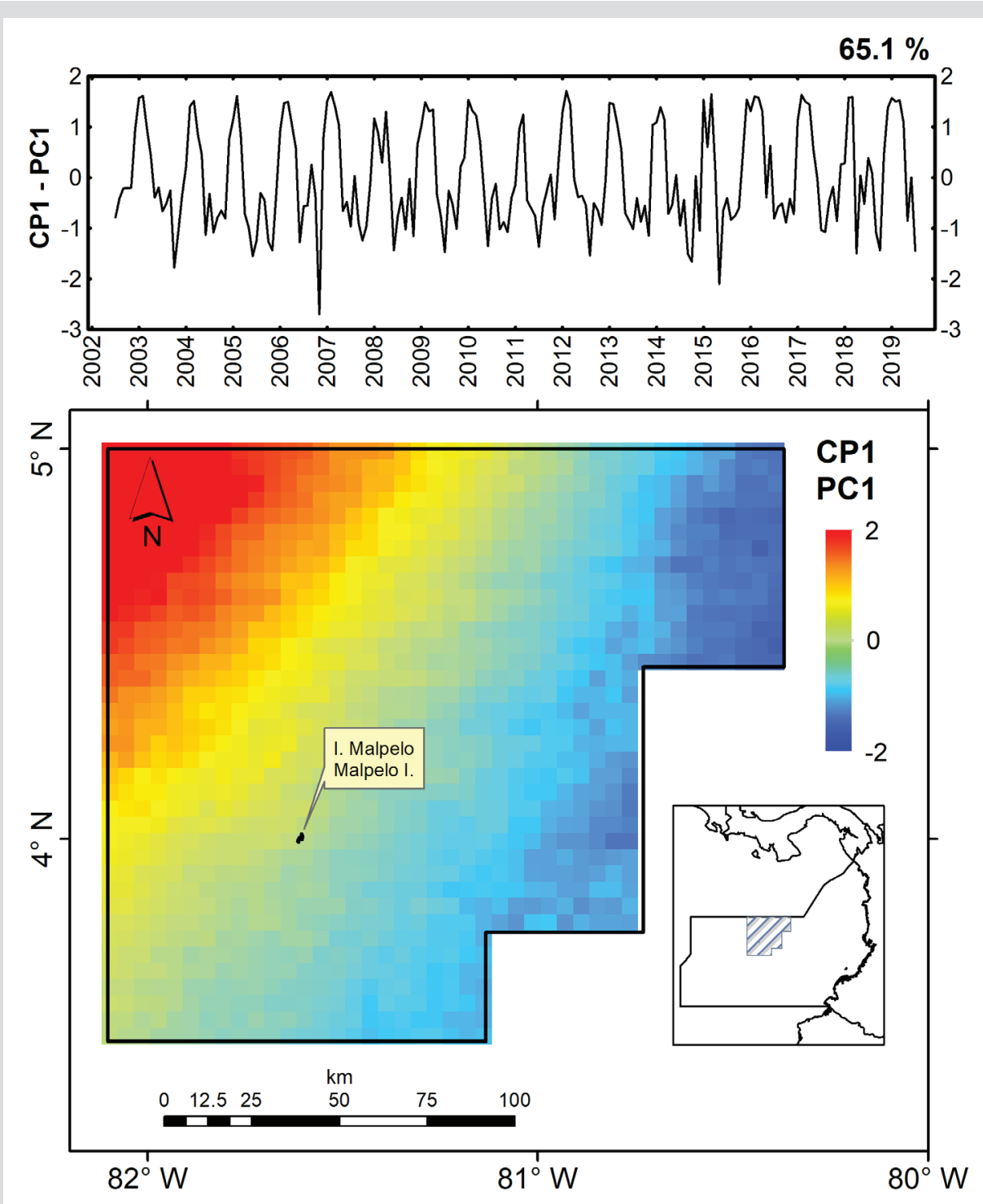

Figura 5. Primer componente principal estandarizado de un análisis de componentes principales de la Temperatura Superficial del Mar (TSM) en el Santuario de Fauna y Flora Malpelo, a partir de datos derivados del sensor Modis-Aqua (2002-2019).
Figure 5. First standardized principal component (PC1) of a principal component analysis of Sea Surface Temperature (SST) in the Malpelo Flora and Fauna Sanctuary, using data derived from the MODIS-Aqua sensor (2002-2019).
Al ajustar los modelos, exponencial, gausiano y esférico por mínimos cuadrados ordinales y ponderados para los datos in situ (Figura 4), la semivarianza fue muy pequeña (meseta) y en todos los casos los cuadrados medios del error fueron iguales a cero.
When the exponential, Gaussian and spherical ordinal least squares and weighted least squares models were fitted to the in situ data (Figure 4), semivariance was very small (plateau) and in all cases the mean squares of the error were equal to zero. 

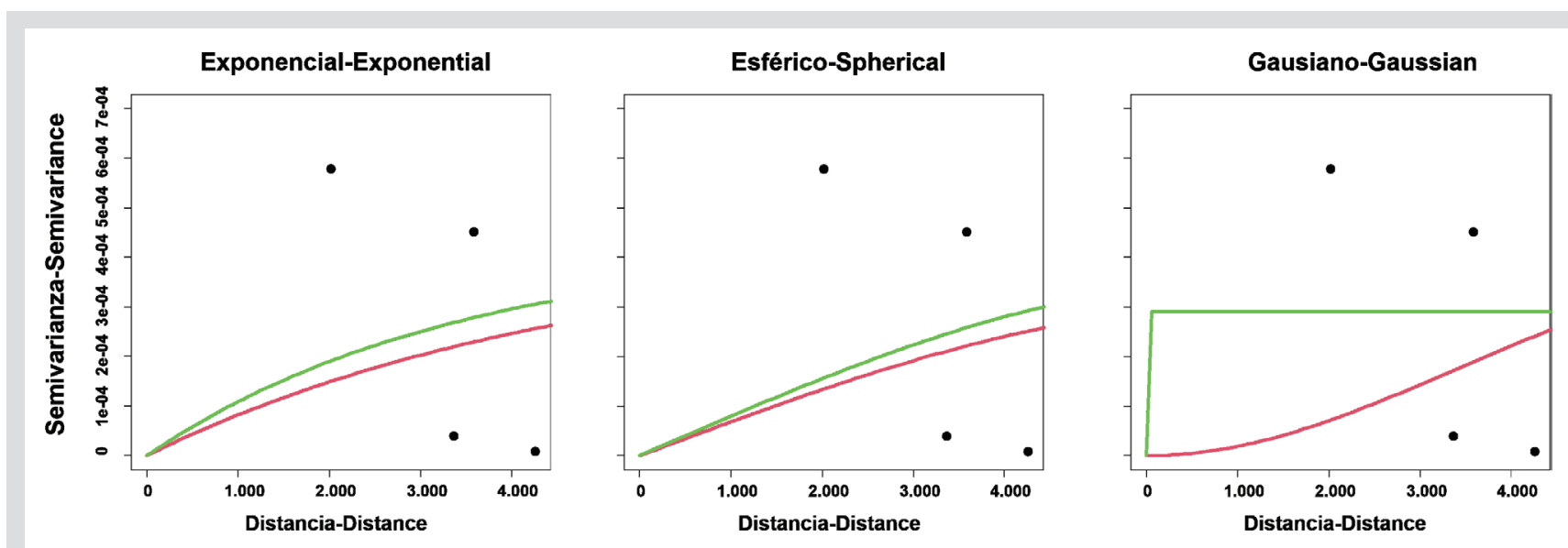

Figura 6. Semivariograma experimental (puntos) y modelos ajustados (línea roja: mínimos cuadrados ordinales, línea verde: mínimos cuadrados ponderados) para los datos de TSM in situ del SFF Malpelo.

Figure 6. Experimental semi-variogram (dots) and fitted models (red line: ordinal least squares, green line: weighted least squares) for the in Las distancias están dadas en metros.

Al ajustar los modelos, exponencial, gausiano y esférico por mínimos cuadrados ordinales y ponderados para los datos derivados de sensores remotos, los modelos de semivarianza ajustados mostraron una fuerte autocorrelación espacial de la TSM. Se encontró que el modelo de mejor ajuste (menor valor de los cuadrados medios del error), fue el modelo gausiano calculado a través de mínimos cuadrados ordinales (Tabla 1, Figura 5). Este modelo presentó una meseta de 73,2 (máxima disimilitud) y un rango de $179340 \mathrm{~m}$.
When fitting the exponential, Gaussian and spherical ordinal least squares and weighted least squares models to the remotely sensed data, the fitted semivariance models showed a strong spatial autocorrelation for SST. The best fitting model (lowest value of error mean squares) was found to be the Gaussian model calculated using ordinal least squares (Table 1, Figure 5). This model presented a plateau of 73.2 (maximum dissimilarity) and a range of $179,340 \mathrm{~m}$.

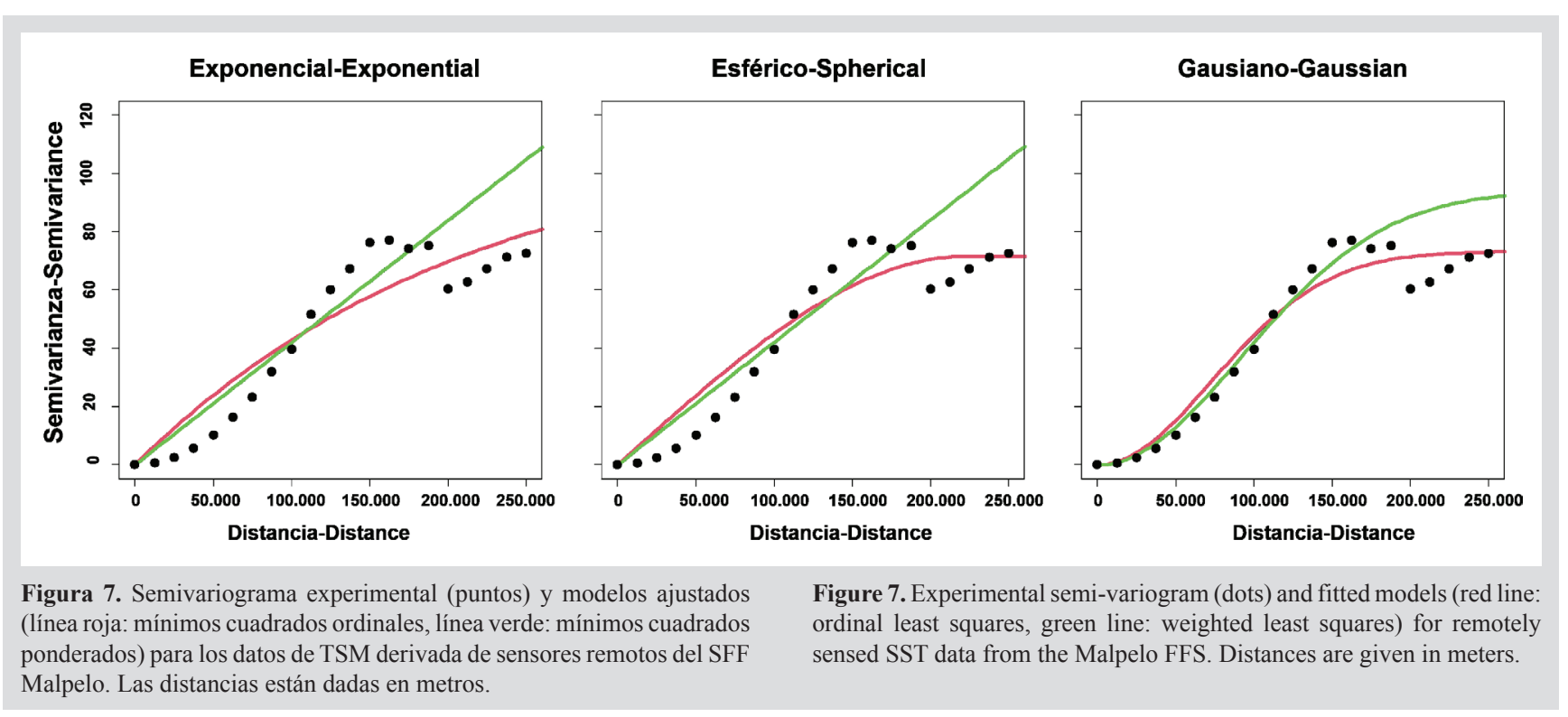


Tabla 1. Modelos de semivarianza teóricos ajustados a los semivariogramas experimentales calculados para la TSM obtenida del sensor remoto MODIS-Aqua.
Table 1. Theoretical semivariance models fitted to experimental semivariograms calculated for SST values obtained from the MODISAqua remote sensor.

\begin{tabular}{|c|c|c|c|c|c|}
\hline $\begin{array}{l}\text { TSM Sensores / } \\
\text { Sensors }\end{array}$ & $\begin{array}{l}\mathrm{T}^{2} \text { (Efecto pepita)/ } \\
\text { (Nugget effect) }\end{array}$ & $\begin{array}{c}\Sigma^{2} \text { (Meseta parcial) } \\
\text { (Partial plateau) }\end{array}$ & $\begin{array}{l}\text { Meseta / } \\
\text { Plateau }\end{array}$ & $\begin{array}{c}\text { Rango / } \\
\text { Range (m) }\end{array}$ & $\begin{array}{c}\Sigma^{2} \text { del error } / \\
\text { Error } \Sigma^{2}\end{array}$ \\
\hline $\begin{array}{l}\text { Exponencial - Mínimos cuadrados ordinales / } \\
\text { Exponential - Ordinal Least Squares }\end{array}$ & 0 & 116.0 & 116.0 & 652,624 & 2,159 \\
\hline $\begin{array}{l}\text { Exponencial - Mínimos cuadrados ponderados / } \\
\text { Exponential - Weighted Least Squares }\end{array}$ & 0 & 587714.7 & 587714.7 & $4,197,903,612$ & $58,431,341$ \\
\hline $\begin{array}{l}\text { Esférico - Mínimos cuadrados ordinales / } \\
\text { Spherical - Ordinal least squares }\end{array}$ & 0 & 71.6 & 71.6 & 222,565 & 1,640 \\
\hline $\begin{array}{l}\text { Esférico - Mínimos cuadrados ponderados / } \\
\text { Spherical - Weighted least squares }\end{array}$ & 0 & 94.1 & 94.1 & 225,465 & $13,255,308$ \\
\hline $\begin{array}{l}\text { Gausiano - Mínimos cuadrados ordinales / } \\
\text { Gaussian - Ordinal least squares }\end{array}$ & 0 & 73.2 & 73.2 & 179,340 & 765 \\
\hline $\begin{array}{l}\text { Gausiano - Mínimos cuadrados ponderados / } \\
\text { Gaussian - Weighted Least Squares }\end{array}$ & 0 & 94.1 & 94.1 & $225,464.7$ & $13,255,308$ \\
\hline
\end{tabular}

Al considerar el modelo gausiano obtenido por mínimos cuadrados ordinales del análisis de la TSM de sensores remotos, el cual fue el modelo de mejor ajuste, $100 \%$ de la disimilitud ocurrió cuando la semivarianza fue igual a 73,2 y el rango $179340 \mathrm{~m}$. La semivarianza puede ser también interpretada como una distancia de disimilitud. Por ejemplo, para el modelo gausiano ajustado, una disimilitud de $20 \%$ está dada a 28,57 km (15,43 millas náuticas) (Tabla 2). Para elegir la distancia idónea entre estaciones también se deben considerar temas logísticos, ya que una malla de muestreo con estaciones muy separadas entre sí y distantes desde la isla Malpelo requeriría grandes desplazamientos que quizás no pueden cubrirse con el tipo de embarcaciones que regularmente realizan los monitoreos oceanográficos en el SFF Malpelo, y con la logística asociada a esos muestreos. Por ejemplo, una malla de muestreo con una forma similar a la actual (Figura 1), con un distanciamiento entre estaciones de $27,78 \mathrm{~km}$ (15 millas náuticas) (actualmente la distancia entre estaciones es entre 0,5 y $1 \mathrm{mn}$ ) y con solo ocho estaciones (dos en cada eje; norte-sur, oeste-este), tomaría más de 38 horas para ser llevada a cabo, solo considerando la navegación entre estaciones, y estimando una velocidad promedio de $11 \mathrm{~km} / \mathrm{h}$ (6 nudos). Actualmente, el monitoreo oceanográfico del SFF Malpelo se realiza principalmente en embarcaciones de buceo con restricciones logísticas para grandes desplazamientos debido a que se realizan otras actividades de monitoreo e investigación. Por lo tanto, es necesario adoptar una malla de muestreo con un espaciado menor entre estaciones. Un criterio adicional para elegir la
The Gaussian model obtained using ordinal least squares from remote sensing SST analysis (the best fitting model), showed that $100 \%$ of the dissimilarity occurred when semivariance was equal to 73.2 and the range was $179,340 \mathrm{~m}$. Semivariance may also be interpreted as a dissimilarity distance. For example, for the fitted Gaussian model, a dissimilarity of $20 \%$ was found at $28.57 \mathrm{~km}(15.43$ nautical miles) (Table 2). To choose the ideal distance between stations, logistical issues must also be considered, as a sampling network with stations that are too far apart and too distant from Malpelo Island would require long journeys that might be beyond the capabilities of the type of vessels that regularly carry out oceanographic monitoring in the Malpelo FFS, and the logistics associated with such sampling would be complicated. For example, a sampling network with a shape similar to the current one (Figure 1) and a distance between stations of $27.78 \mathrm{~km}(15 \mathrm{~nm})$ (currently the distance between stations is between 0.5 and $1 \mathrm{~nm}$ ) and with only eight stations (two on each axis; north-south, west-east), would take more than 38 hours to complete at an average speed of $11 \mathrm{~km} / \mathrm{h}$ (6 knots). Currently, oceanographic monitoring of the Malpelo FFS is principally carried out using dive ships, which have logistical restrictions that hinder long journeys, because they also carry out other monitoring and research activities. It is therefore necessary to adopt a sampling network with shorter distances between stations. An additional criterion for choosing the gaps between stations is the prediction error (Table 3). An evaluation of this parameter in sampling 
distancia entre estaciones es el error de predicción (Tabla 3). Al evaluar este parámetro en mallas de muestreo a tres distancias diferentes: 27,78, 14,82 y 7,41 km $(15,8$ y 4 millas nauticas), se encontró que este aumenta de forma exponencial en función de la distancia entre los puntos de muestreo, y en todos los casos fue menor a $2 \%$. No obstante, la malla de muestreo con estaciones cada $7,41 \mathrm{~km}$ (4 millas náuticas) presentó el menor error de predicción. Este valor se aproxima al obtenido en la Tabla 2, cuando el modelo de semivarianza presenta una disimilitud entre estaciones de $5 \%(7,14 \mathrm{~km} ; 3,86$ millas náuticas). networks at three different distances $(27.78,14.82$ and 7.41 $\mathrm{km}-15,8$ and $4 \mathrm{~nm}$ ) found that it increases exponentially as a function of the distance between sampling points, and was in all cases less than $2 \%$. However, the sampling network with stations every $7.41 \mathrm{~km}(4 \mathrm{~nm})$ returned the lowest prediction error. This value is close to that obtained in Table 2 , in which the semivariance model presents a dissimilarity between stations of $5 \%$ (7.14 km, 3.86 nautical miles).
Tabla 2. Distancia asociada a valores discretos de disimilitud, obtenida a partir de la semivarianza de un modelo gausiano de la TSM del SFF Malpelo.
Table 2. Distance associated with discrete values of dissimilarity, obtained using the Gaussian semivariance model of SST in the Malpelo FFS.

\begin{tabular}{|c|c|c|}
\hline \multirow{2}{*}{ Dismilitud / Dissimilitude (\%) } & \multicolumn{2}{|c|}{ Distancia / Distance } \\
\hline & km & millas náuticas / nautical miles \\
\hline 100 & 179.34 & 96.84 \\
\hline 90 & 128.57 & 69.42 \\
\hline 80 & 114.29 & 61.71 \\
\hline 70 & 100.00 & 54.00 \\
\hline 60 & 85.71 & 46.28 \\
\hline 50 & 71.43 & 38.57 \\
\hline 40 & 57.14 & 30.85 \\
\hline 30 & 42.86 & 23.14 \\
\hline 20 & 28.57 & 15.43 \\
\hline 10 & 14.29 & 7.71 \\
\hline 5 & 7.14 & 3.86 \\
\hline 2.5 & 3.57 & 1.93 \\
\hline 1 & 1.43 & 0.77 \\
\hline 0 & 0.00 & 0.00 \\
\hline
\end{tabular}

Por lo tanto, si se utiliza una distancia entre estaciones de 7,41 km (4 millas náuticas) (distancia con el menor error de predicción) la malla de muestreo para toda el área del Santuario tendría 598 estaciones, lo cual desde el punto de vista logístico difícilmente puede llegar a cubrirse. Considerando las limitaciones logísticas y de desplazamiento, y generando áreas de influencia alrededor de la isla de 9,26 km (5 millas náuticas) y 18,52 km (10 millas náuticas), las cuales corresponden a los dos primeros anillos de muestreo de la malla de 598 estaciones, se obtiene una malla de 8 y 24 estaciones, respectivamente (Figura 6).
Thus, if a distance between stations of $7.41 \mathrm{~km} \mathrm{(4}$ $\mathrm{nm}$ ) is used (the distance with the smallest prediction error) the sampling network for the entire sanctuary area would contain 598 stations, which from a logistical point of view would be difficult to achieve. If the limitations associated with logistics and travel distance are considered, and areas of influence established around the island of $9.26 \mathrm{~km} \mathrm{(5}$ $\mathrm{nm})$ and $18.52 \mathrm{~km}(10 \mathrm{~nm})$-corresponding to the first two sampling rings of the 598-station network- is obtained a network consisting of 8 and 24 stations, respectively (Figure 6). Although other additional sampling rings could 
A pesar de que podrían incluirse otros anillos adicionales de muestreo, la propuesta no los ha considerado debido a que el siguiente anillo de $27,78 \mathrm{~km}$ (15 millas náuticas) incluiría 48 estaciones, lo cual no puede ser cubierto con las condiciones actuales en lo relacionado con desplazamiento y logística. Adicionalmente, debe considerarse que el área de Malpelo presenta una fuerte influencia del sistema de corrientes de la EP. De acuerdo con Metoceanica (2017), durante el primer trimestre del año en las aguas del SFF Malpelo hay un patrón predominante con dirección nororiente-suroccidente, mientras que durante el tercer trimestre del año el patrón es noroccidente-suroriente. Es decir, que los ejes de ubicación de las estaciones deberían tener una inclinación de $45^{\circ}$ y $-45^{\circ}$, formando una " $X$ ", de manera que el muestreo $y / o$ monitoreo pueda capturar la variabilidad generada por el patrón de corrientes.

Tabla 3. Varianza de predicción máxima de la temperatura superficial del mar obtenida a partir del sensor remoto MODIS-Aqua en diferentes mallas de muestreo con estaciones a 7,41 km (4 millas náuticas), 14,82 km (8 millas náuticas) y $27,78 \mathrm{~km}$ (15 millas náuticas). be included, this proposal has not considered them because the next ring of $27.78 \mathrm{~km}(15 \mathrm{~nm})$ would include 48 stations, implying distances and logistical challenges that current conditions would render untenable. Additionally, it should be borne in mind that the Malpelo area is subject to the powerful influence of the PB current system. According to Metoceanica (2017), during the first quarter of the year, the waters of the Malpelo FFS are dominated by northeastsouthwest currents, while during the third quarter the pattern is northwest-southeast. In other words, the station location axes should have an inclination of $45^{\circ}$ and $-45^{\circ}$, forming an "X", so that sampling and/or monitoring can capture the variability generated by current patterns.

Table 3. Maximum prediction variance of Sea Surface Temperature (SST) obtained from the MODIS-Aqua remote sensor in different sampling networks, with the following distances between stations: $7.41 \mathrm{~km} \mathrm{(4}$ nautical miles), $14.82 \mathrm{~km}(8 \mathrm{~nm})$ and $27.78 \mathrm{~km}(15 \mathrm{~nm})$.

\begin{tabular}{|l|c|c|c|}
\cline { 2 - 4 } \multicolumn{1}{c|}{} & \multicolumn{3}{|c|}{$\begin{array}{c}\text { Distancia entre estaciones de muestreo en millas náuticas / } \\
\text { Distance between sampling stations in nautical miles }\end{array}$} \\
\cline { 2 - 5 } & 4 & $\mathbf{8}$ & 15 \\
\hline Error de predicción / Prediction error & 0.5961 & 0.8414 & 1.4774 \\
\hline
\end{tabular}

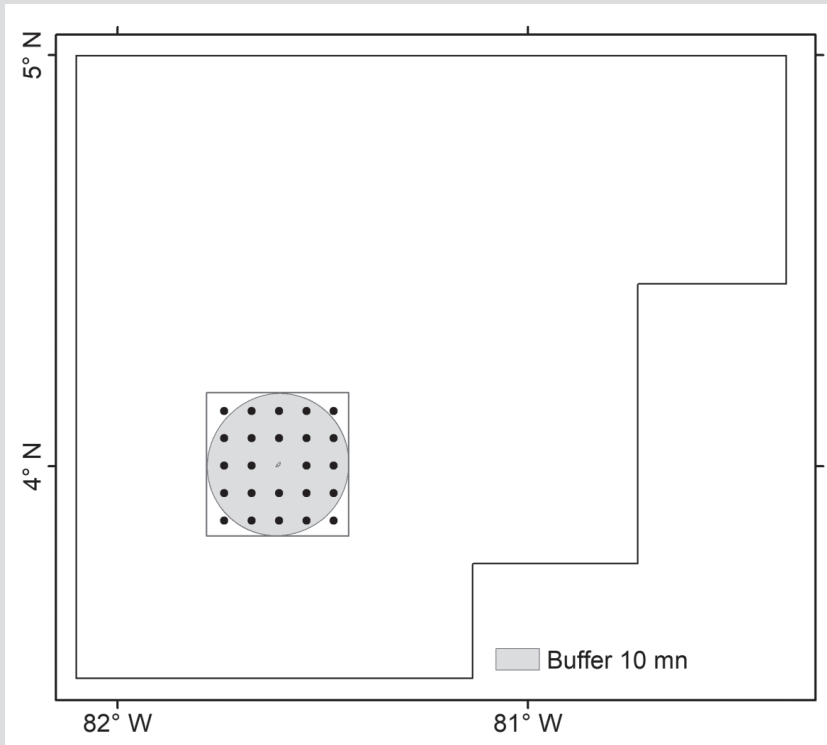

Figura 8. Malla de muestreo para el monitoreo oceanográfico del SFF Malpelo, con distancia entre estaciones de 7,41 km (4 millas nauticas), y para un área de influencia de $18,52 \mathrm{~km}$ (10 millas náuticas) y 9,26 km (5 millas náuticas).

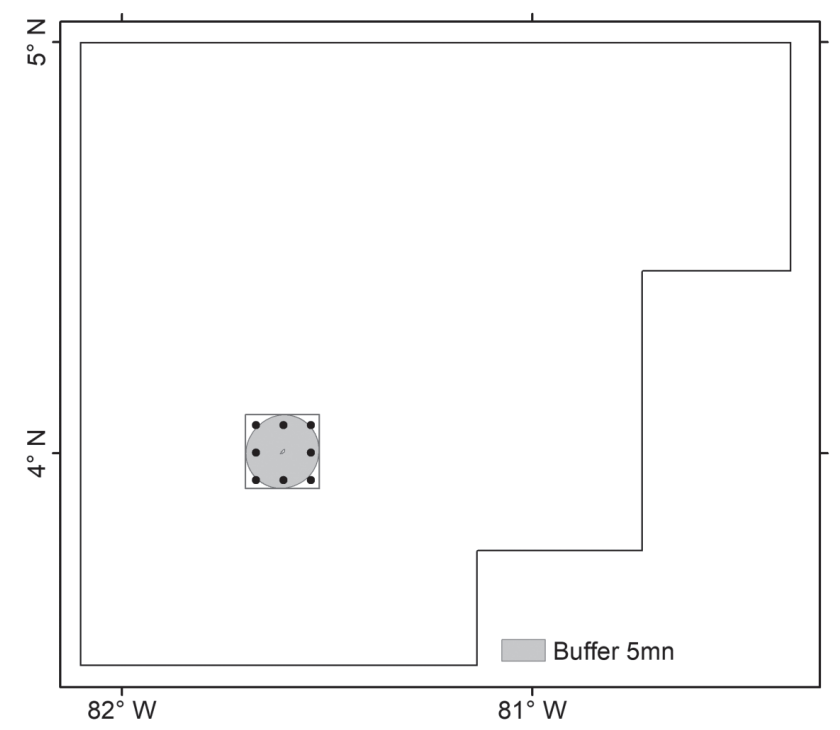

Figure 8. Sampling network for oceanographic monitoring of the Malpelo FFS, with a distance between stations of $7.41 \mathrm{~km}(4 \mathrm{~nm})$ and for an area of influence of $18.52 \mathrm{~km}(10 \mathrm{~nm})$ (left) and $9.26 \mathrm{~km}(5 \mathrm{~nm})$ (right). 
Partiendo de la propuesta de 24 estaciones (Figura 6), centrándolas en relación a la isla y seleccionando solo las estaciones sobre los ejes de desplazamiento de las corrientes, se obtiene una malla de muestreo de ocho estaciones (Figura 7), la cual presenta una disimilitud entre estaciones cercana a $5 \%$, un error de predicción menor a $1 \%$, además de ajustarse a las limitaciones logísticas y de desplazamiento de las embarcaciones con las que regularmente se realizan los monitoreos oceanográficos en el SFF Malpelo. Por lo tanto, la malla de muestreo propuesta incluye ocho nuevas estaciones y plantea mantener las seis estaciones que se han venido haciendo históricamente en el monitoreo oceanográfico, para un total de 14 estaciones (Figura 7). Sin embargo, este número podría reducirse a cuatro y mantener solo las más cercanas a los ejes de desplazamiento de las corrientes (MS, ME1, MN, y MW1). Debido a la poca distancia que hay entre las estaciones de la malla de muestreo actual, las posiciones en las que se han realizado históricamente los muestreos, no coinciden con la posición esperada (Figura 1). Por lo tanto, fue necesario, ajustarlas de acuerdo a la posición más frecuente en la que se realizó cada estación durante el período 2012-2019 y se reubicaron como lo muestra la Figura 7. La Tabla 4 presenta las posiciones en coordenadas geográficas (Sistema de referencia WGS84) y en coordenadas planas (Magna Colombia Oeste), de la malla óptima de muestreo de 14 estaciones para realizar el monitoreo de condiciones oceanográficas en el SFF Malpelo. Al sobreponer una imagen de TSM del sensor Modis-Aqua (julio de 2019) y realizar un muestreo virtual para las estaciones de la malla antigua $(n=6)$ y de la malla propuesta (incluyendo las estaciones antiguas; $n=14$ ), se encuentra que para la malla antigua el promedio es $27,54{ }^{\circ} \mathrm{C}$, el rango (valor máximo menos valor mínimo) es $0,26{ }^{\circ} \mathrm{C}$, la desviación estándar es 0,12 y el coeficiente de variación es 0,29 . De otro lado, estas mismas medidas para la malla propuesta son $27,57^{\circ} \mathrm{C} ; 0,49{ }^{\circ} \mathrm{C} ; 0,33$ y 0,50 , respectivamente.
Starting from a proposed 24 stations (Figure 6) centred on the island, and selecting only the stations on the displacement axes of the currents, a sampling network of eight stations is obtained (Figure 7), producing a dissimilarity between stations close to $5 \%$, a prediction error of less than $1 \%$ and an arrangement that responds to the logistical and range limitations of the vessels that regularly carry out oceanographic monitoring in the Malpelo FFS. Therefore, the proposed sampling network includes eight new stations and proposes maintaining the six stations that have historically been used for oceanographic monitoring, for a total of 14 stations (Figure 7). However, the number of existing stations retained could be reduced from six to four, by preserving only those closest to the displacement axes of the currents (MS, ME1, MN, and MW1). Due to the short distances between the stations in the current sampling network, the positions at which sampling has been historically performed do not coincide where in which the station should have been madepositioned (Figure 1). It was therefore, was necessary to adjust the station positions according to the most frequent position in which each station was realizedestablished during the period 2012-2019. These were relocated as shown in Figure 7. Table 4 presents these positions using geographic and plan coordinates (WGS84 reference system and MAGNA Colombia West, respectively), setting out the optimal sampling network of 14 stations for monitoring oceanographic conditions in the Malpelo FFS. By superimposing a SST image derived from the MODIS-Aqua sensor (July 2019) and performing a virtual sampling procedure for the stations of the old network $(\mathrm{n}=6)$ and of the one proposed here (including the old stations; $n=14$ ), it is found that for the old network the average is $27.54{ }^{\circ} \mathrm{C}$, the range (maximum value minus minimum value) is $0.26^{\circ} \mathrm{C}$, standard deviation is 0.12 and the coefficient of variation is 0.29 . On the other hand, the equivalent measurements for the proposed network are $27.57^{\circ} \mathrm{C}, 0.49^{\circ} \mathrm{C}, 0.33$ and 0.50 , respectively. 


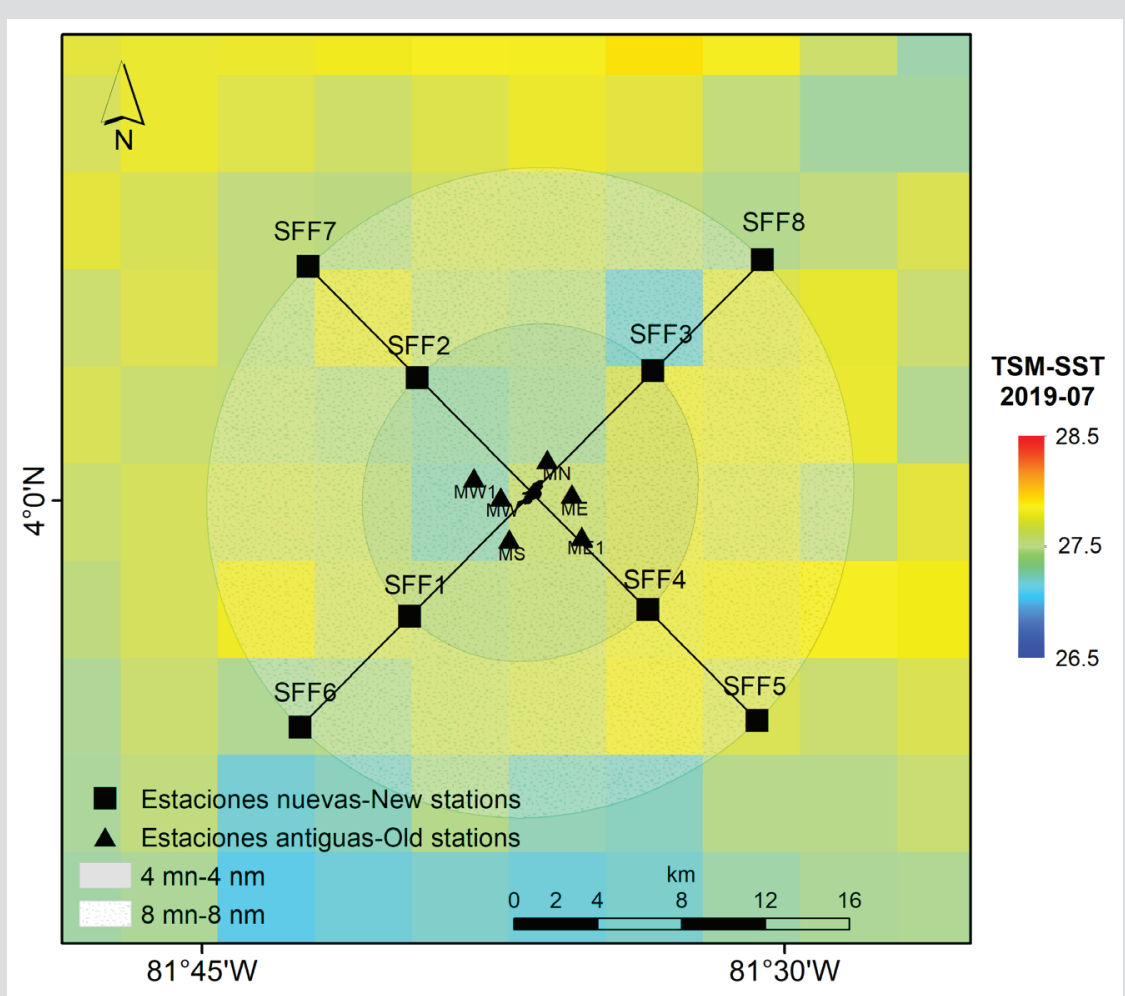

Figura 9. Propuesta de malla de muestreo para el monitoreo oceanográfico del SFF Malpelo, con distancia entre estaciones de 7,41 $\mathrm{km}$ (4 millas náuticas) alrededor de isla Malpelo y considerando los ejes de desplazamiento de las corrientes. De fondo se presenta una imagen de Temperatura Superficial del Mar (TSM) del sensor Modis-Aqua de julio de 2019.
Figure 9. Sampling network proposed for the oceanographic monitoring of the Malpelo FFS, with a distance between stations of $7.41 \mathrm{~km}(4 \mathrm{~nm})$ around Malpelo Island and taking into consideration the displacement axes of the currents. A Sea Surface Temperature (SST) image from the MODIS-Aqua sensor of July 2019 is superimposed.
Tabla 4. Posiciones en coordenadas geográficas (GCS_WGS_1984) y planas (MAGNA Colombia Oeste), de las estaciones de la malla de muestreo para el muestreo oceanográfico en el SFF Malpelo.
Table 4. Positions in geographic (GCS_WGS_1984) and planar coordinates (MAGNA Colombia West) of the stations of the sampling network for oceanographic sampling in the Malpelo FFS.

\begin{tabular}{|c|c|c|c|c|}
\hline Estación / Station & Longitud / Length & Latitud / Latitude & Estes / East & Nortes / North \\
\hline MS & -81.61786 & 3.98344 & 495256.38405 & 933632.30082 \\
\hline MN & -81.60153 & 4.01762 & 497096.54098 & 937413.48901 \\
\hline ME & -81.59109 & 4.00290 & 498250.56670 & 935773.78473 \\
\hline ME1 & -81.58680 & 3.98460 & 498716.56997 & 933741.96198 \\
\hline MW & -81.62152 & 4.00156 & 494859.91177 & 93644.04388 \\
\hline MW1 & -81.63303 & 4.00986 & 493582.62663 & 929974.77300 \\
\hline SFF1 / FFS1 & -81.66067 & 3.95023 & 490466.55100 & 930247.82200 \\
\hline SFF4 / FFS4 & -81.55844 & 3.95325 & 501857.22200 & 941326.06500 \\
\hline SFF2 / FFS2 & -81.65745 & 4.05258 & 490889.33200 & 941611.10400 \\
\hline SFF3 / FFS3 & -81.55626 & 4.05571 & 502162.78800 & 946850.54500 \\
\hline SFF8 / FFS8 & -81.50915 & 4.10322 & 507438.15000 & 946656.11200 \\
\hline SFF7 / FFS7 & -81.70433 & 4.10035 & 485696.72900 & 924930.13800 \\
\hline SFF5 / FFS5 & -81.51155 & 3.90556 & 507052.17700 & 924732.93300 \\
\hline SFF6 / FFS6 & -81.70776 & 3.90272 & 485190.49900 & \\
\hline
\end{tabular}




\section{DISCUSIÓN}

El esfuerzo que ha hecho la dirección territorial Pacífico (DTPA) de Parques Nacionales Naturales (PNN) para mantener un monitoreo de condiciones oceanográficas en el SFF Malpelo a través del tiempo es inmenso. Desde su inicio en 2006 han tenido que sortear las dificultades logísticas que implica realizar muestreos en una zona oceánica y remota, haciendo uso de plataformas de oportunidad como los barcos de buceo. No obstante, los muestreos se han realizado sobre una malla de muestreo con un reducido número de estaciones, y con una distancia muy corta entre ellas, por lo que la variabilidad espacial capturada por esta malla de muestreo es limitada. No se tiene conocimiento de cuáles fueron los criterios usados para disponer las estaciones en la malla de muestreo actual, pero se ha hecho así desde el comienzo. En términos de la variabilidad temporal, la cobertura también es insuficiente debido a la dificultad de mantener un monitoreo continuo o mensual en esa zona remota. Sin embargo, siempre se ha buscado realizar los muestreos en al menos uno de los meses de las dos temporadas contrastantes. Entre febreroabril, cuando predominan los vientos alisios del norte y ocurre la surgencia estacional y una disminución de la TSM, la cual es generada por el chorro de vientos de jet de Panamá (Chelton et al., 2000) y entre septiembre-octubre, cuando predominan los vientos alisios del sur y la TSM es mayor que durante el primer semestre del año.

Un monitoreo de condiciones biológicas $\mathrm{u}$ oceanográficas en sistemas marinos o acuáticos, debe permitir tener un punto de vista integrador y capturar la mayor variabilidad posible en diferentes escalas espaciales y temporales. También debe garantizar que la disposición de las estaciones no sea redundante, debido a que esto incrementaría los costos innecesariamente. En el arreglo espacial de estaciones de muestreo, la aproximación más común para el diseño de una red o malla de muestreo incluye los cuadrantes y los transectos, bajo el supuesto de que la muestras son independientes. Sin embargo, otra alternativa que puede llegar a ser más robusta, es asumir que el fenómeno a ser estudiado representa un proceso estocástico en el cual la variable medida es regionalizada y se estudia su estructura de autocorrelación espacial. Al respecto, Giraldo et al. (2001) y Giraldo (2002) proponen procedimientos que son basados en criterios asociados con la distancia entre pares de puntos de manera que se pueda calcular un semivariograma, y esa ha sido la aproximación abordada en este trabajo.

\section{DISCUSSION}

The efforts of the Pacific Territorial Directorate (DTPA in spanish) of the National Natural Parks (NNP) to maintain monitoring of oceanographic conditions in the Malpelo FFS over time have been immense. Since the initiation of the process in 2006, the DTPA has had to overcome the logistical difficulties of sampling in a remote oceanic area and been obliged to make use of available platforms, such as dive ships. However, the surveys have been conducted on a sampling network with a small number of stations, separated by very short distances, with the result that the spatial variability captured by the network is limited. It is not known what criteria were used to arrange the stations in the current sampling network, but it has remained unchanged since the beginning. In terms of temporal variability, the coverage is also insufficient, due to the difficulty of maintaining continuous or monthly monitoring in this remote area. However, sampling has always been attempted in at least one of the months of the two contrasting seasons, namely between February and April, when the northern trade winds predominate and seasonal upwelling and SST decrease because of the winds of the Panama jet (Chelton et al., 2000) and between SeptemberOctober, when the southern trade winds predominate and SST is higher than during the first half of the year.

The monitoring of biological or oceanographic conditions in marine or aquatic systems should allow for a unifying approach and capture as much variability as possible along different spatial and temporal scales. It should also ensure that the arrangement of stations is not redundant, as this unnecessarily increases costs. In the spatial arrangement of sampling stations, the most common approach to the design of a sampling network involves the use of quadrats and transects, according to the assumption that the samples are independent. However, a possibly more robust alternative is to assume that the phenomenon to be studied represents a stochastic process in which the measured variable is regionalized which allowsmaking it possible to study its spatial autocorrelation structure. In this regard, Giraldo et al. (2001) and Giraldo (2002) propose procedures that are based on criteria associated with the distance between pairs of points, such that a semivariogram can be calculated. This has been the approach used in this paper.

When fitting the semivariograms for the in situ SST data, the mean squares of the error were equal to zero. This 
Al ajustar los semivariogramas para los datos de TSM in situ, los cuadrados medios del error fueron iguales a cero. Esto es un indicador de que la distancia entre las estaciones del muestreo in situ no es lo suficiente para que haya una variabilidad o disimilitud considerable de la TSM, o el número de estaciones es insuficiente, Por lo tanto, a partir de este conjunto de datos no fue posible construir un modelo de semivarianza robusto que permitiera brindar información para el ajuste de la malla de muestreo en el SFF Malpelo. Lo anterior, refuerza la necesidad de ampliar el número de estaciones de la malla de muestreo oceanográfico del SFF Malpelo.

El rango encontrado en el modelo de mejor ajuste (179.340 m para el análisis con los datos de la TSM derivada de sensores remotos, es relativamente alto si se tiene en cuenta que la distancia máxima entre los extremos suroccidental y nororiental del Santuario es de 255,3 km (137,8 millas náuticas). Es decir que, en el SFF Malpelo dos valores de TSM son independientes a una distancia de 179,3 km (96,8 millas náuticas). A distancias menores los valores estarán autocorrelacionados espacialmente. De acuerdo con Giraldo et al. (2001), esta condición es ideal debido a que las predicciones obtenidas por interpolaciones geoestadísticas tendrán una menor varianza y un menor error de predicción, como el encontrado en la malla de muestreo con estaciones cada 7,41 km (4 millas náuticas), por lo que se requerirá un reducido número de sitios de muestreo y se podrán obtener intervalos de confianza reducidos al estimar la variable. La malla de muestreo propuesta, la cual incluye los dos primeros anillos de la malla de 7,41 km, considera además de la variabilidad espacial estudiada mediante los semivariogramas, el sistema de corrientes predominante en el área el cual es dominado durante el primer trimestre del año por el giro ciclónico asociado al efecto del chorro de viento del jet de Panamá y por el desarrollo, durante el dominio de los alisios del suroeste, de un giro anticiclónico en el sector oriental de la EP y un giro ciclónico en el sector oeste (Rodríguez-Rubio y Giraldo, 2011).

Dado que la malla de muestreo propuesta ha considerado las limitaciones logísticas y ha limitado el número de estaciones a los dos primeros anillos de una malla ideal de 598 estaciones, la propuesta para monitorear las condiciones oceanográficas del SFF Malpelo puede ser modificada en la medida en que las condiciones de muestreo puedan mejorarse. Si se pudiera contar con una embarcación apropiada para las exigencias de la zona oceánica y con una dedicación exclusiva para el monitoreo is an indicator either that the distance between the in situ sampling stations is insufficient for there to be considerable SST variability or dissimilarity, or that there are too few stations. Therefore, from this data set it was not possible to construct a robust semivariogram model that would provide information useful for adjusting the sampling network in the Malpelo FFS. This reinforces the need to increase the number of stations in the oceanographic sampling network of the Malpelo FFS.

The range found in the best fit model $(179,340$ $\mathrm{m}$ for the analysis with remotely sensed SST data) is relatively high considering that the maximum distance between the southwestern and north-eastern ends of the sanctuary is $255.3 \mathrm{~km}(137.8 \mathrm{~nm})$. In other words, in the Malpelo FFS two SST values are independent at $179.3 \mathrm{~km}$ $(96.8 \mathrm{~nm})$. At shorter distances the values will be spatially autocorrelated. According to Giraldo et al. (2001), this condition is ideal because the predictions obtained by geostatistical interpolations will have a lower variance and a lower prediction error, as found in the sampling network with stations every $7.41 \mathrm{~km}(4 \mathrm{~nm})$. Therefore, a reduced number of sampling sites will be required and reduced confidence intervalsmight be obtained when the variable is estimated. In addition to the spatial variation examined with reference to semivariograms, the proposal for the new sampling network presented here -which includes the first two rings of the $7.41 \mathrm{~km}$ network - takes into account the dominant effects during the first quarter of the year of the cyclonic gyre associated with the effect of the Panama jet and the development, during the period of dominance of the southwest trade winds, of an anticyclonic gyre in the eastern sector of the PB and a cyclonic gyre in the western sector (Rodríguez-Rubio and Giraldo, 2011).

Since the proposed sampling network took logistical limitations into account and limited the number of stations to the first two rings of an ideal network of 598 stations, the proposal to monitor the oceanographic conditions of the Malpelo FFS may be modified to the extent that the sampling conditions might improve. If a vessel appropriate to the demands of the oceanic zone and dedicated exclusively to oceanographic monitoring were available, a third sampling ring could be added. It should be clear that in either case the area of coverage is still insufficient. Of the 2,709,612.8 ha that currently make up the sanctuary, the proposed expansion of the sampling network only covers 49,568 ( $1.83 \%$ of the protected area). Therefore, in a sector such as the Malpelo FFS, whose vast marine area represents 
oceanográfico se podría incluir el tercer anillo de muestreo. Se debe tener claro que en cualquiera de los casos el área de cobertura sigue siendo insuficiente. De las 2709 612,8 ha con las que actualmente cuenta el Santuario, la propuesta de ampliación de la malla de muestreo solo cubre 49,568 ha ( $1,83 \%$ del área protegida). Por lo tanto, en un sector como la del SFF Malpelo, la cual cuenta con una vasta área marina que representa grandes desafíos logísticos y económicos para realizar un muestreo continuo en el tiempo y con una malla de estaciones adecuada para capturar la variabilidad de los procesos, es necesario complementar los monitoreos in situ, con sensoramiento remoto. Esto permitirá evaluar la variabilidad en diferentes escalas espaciales y temporales, y guiar de una manera más acertada la toma de decisiones de manejo.

\section{CONCLUSIONES}

La malla de muestreo actual para el monitoreo oceanográfico del SFF Malpelo, la cual cuenta con estaciones cada $0,93 \mathrm{~km}(0,5$ millas náuticas $)$ y $1,85 \mathrm{~km}$ (1 milla náutica), presentó una variabilidad espacial reducida que evidencia que durante el período 20062019 el monitoreo se realizó sobre un cuerpo de agua con características similares en superficie, por lo que se podría presumir que fue redundante. Además de haber cubierto un área muy reducida, los modelos de semivarianza indicaron que se hubiera podido lograr los mismos resultados con un número menor de estaciones. Por lo tanto, la propuesta de ampliación de la malla de muestreo responde a una necesidad del área protegida, ya que la nueva malla de muestreo permitirá capturar una mayor variabilidad de los procesos asociados a la temperatura del mar. En este sentido, la decisión para proponer una nueva malla de muestreo se basó en la disimilitud entre estaciones asociada al modelo de semivarianza, en la varianza del error de predicción, en el patrón de corrientes marinas predominante durante el ciclo anual, y en aspectos logísticos relacionados con las limitantes de desplazamiento de las embarcaciones que realizan los monitoreos oceanográficos en el SFF Malpelo. La malla de muestreo propuesta cuenta con ocho estaciones nuevas y se plantea adicionalmente la posibilidad de mantener las seis estaciones históricas, aunque este número podría reducirse a solo cuatro, para un total de 12 estaciones.

De acuerdo al Plan de Manejo del área protegida (Parques Nacionales Naturales, 2015), el componente oceanográfico es de gran importancia para comprender great logistical and economic challenges to maintaining continuous sampling over time using a network of stations that is sufficient to capture the variability of the processes involved, in situ monitoring should be complemented with remote sensing. This would make it possible to evaluate variability at different spatial and temporal scales and to guide management decisions more accurately.

\section{CONCLUSIONS}

The current sampling network used for the oceanographic monitoring of the Malpelo FFS, which has stations located at $0.93 \mathrm{~km}(0.5 \mathrm{~nm})$ and $1.85 \mathrm{~km}(1 \mathrm{~nm})$, from the island, presented reduced spatial variability, showing that during the period 2006-2019 the monitoring was conducted over a body of water with similar surface characteristics, allowing it to be assumed that the sampling was redundant. In addition to it covering a very small area, the semivariance models indicated that the same results could have been achieved with a smaller number of stations. Therefore, the proposal to expand the sampling network responds to the needs of the protected area, since the new sampling network will permit the capture of a greater variability of the processes associated with sea temperature. In this sense, the decision to propose a new sampling network was based on the dissimilarity between stations associated with the semivariance model, the variance of the prediction error, the predominant marine current pattern during the annual cycle and logistical aspects related to the limitations of the distances covered by the vessels that carry out oceanographic monitoring in the Malpelo FFS. The proposed sampling network has eight new stations. The possibility of maintaining the six historical stations is also considered, although this number could be reduced to only four, for a total of 12 stations.

According to the Management Plan of the protected area (Parques Nacionales Naturales, 2015), the oceanographic component is of great importance to ensuring understanding of the distribution and abundance of the protected area's conservation assets and guiding management strategies. This is why it is important to maintain a continuous record of physical, chemical and biological variables in the area. This requires a specific work platform that can remain in the area long enough to carry out the required sampling, something that may not be possible due to logistical and economic restrictions. Therefore, given the challenge of monitoring oceanographic conditions in the 
la distribución y la abundancia de los valores objeto de conservación del área protegida y para orientar las estrategias de manejo, por lo cual es necesario mantener un registro continuo de variables físicas, químicas y biológicas en el área. Para esto se requiere de una plataforma de trabajo específica que pueda permanecer en el área el tiempo necesario para llevar a cabo los muestreos requeridos, lo cual puede no lograrse debido a restricciones logísticas y económicas. Por lo tanto, ante el desafío que representa el monitoreo de las condiciones oceanográficas en el SFF Malpelo, por su tamaño y por su distancia desde la costa, el sensoramiento remoto es una alternativa costo-eficiente que permite tener un monitoreo continuo en el espacio y el tiempo, y se constituye como una herramienta alternativa para generar información complementaria a los muestreos que se hacen ocasionalmente in situ.

\section{AGRADECIMIENTOS}

Este estudio fue realizado en el marco del convenio interadministrativo 002 de 2019 suscrito entre la Dirección Territorial Pacífico de Parques Nacionales Naturales y la Universidad del Valle. Se agradece a Katherine Muñoz, coordinadora oficina de extensión, Facultad de Ciencias, Universidad del Valle, por su eficiente gestión en la ejecución del convenio.
Malpelo FFS associated with its size and its distance from the coast, remote sensing is a cost-effective alternative that allows continuous monitoring in space and time, and is an alternative tool that could be used to generate information complementary to occasional in situ sampling.

\section{ACKNOWLEDGMENTS}

This study was conducted within the framework of Inter-Administrative Agreement 002 of 2019, signed between the Pacific Territorial Directorate of the National Natural Parks and the Universidad del Valle. Thanks are due to Katherine Muñoz, extension office coordinator, Faculty of Sciences, Universidad del Valle, for her efficient management of the implementation of the agreement.

\section{BIBLIOGRAFÍA / LITERATURE CITED}

Amador, J., E.J. Alfaro, O.G. Lizano and V.O. Magaña. 2006. Atmospheric forcing of the eastern tropical Pacific: A review. Prog. Oceanogr., 69: 101-142. doi:10.1016/j.pocean.2006.03.007

CCO y Dimar. 2019. Malpelo es Colombia, maravilla estratégica. CCO, Bogotá, D.C.

Chelton, D.B., M. H. Freilich and S.K. Esbensen. 2000. Satellite observations of the wind jets off the Pacific coast of Central America. Part II: Relationships and dynamical considerations. Month. Weath. Rev., 128: 2019-2043. doi:10.1175/1520-0493(2000)128<2019:SOOTWJ>2.0.CO;2

Cressie, N. 1989. Geostatistics. Am. Statistic., 43(4): 611-623.

Cressie, N. 1993. Statistical for spatial data. Wiley, 900 p. doi:10.1002/9781119115151

Emery, W.J. and R.E. Thompson. 2014. Data analysis methods in physical oceanography. 3rd ed. Elsevier Science, 654 p. doi.org/10.1016/B978-0-44450756-3.X5000-X

Fiedler, P. and L. Talley. 2006. Hydrography of the eastern tropical Pacific: A review. Progr. Oceanogr., 69: 143-180. doi:10.1016/j.pocean.2006.03.008

Forsbergh, E.D. 1969. Estudio sobre la climatología, oceanografía y pesquerías del Panamá Bight. Bull. Inter. Am. Trop. Tuna Comm., 14: 49-365.

Giraldo, R. 2002. Introducción a la geoestadística: teoría y aplicación, Universidad Nacional de Colombia, Bogotá, D.C., 94 p.

Giraldo, R., N. Méndez and D. Ospina. 2001. Design of a sampling network for an estuary in the Colombian Caribbean. Rev. Acad. Colomb. Cienc., 25(97): 509-518.

Kessler, W. 2006. The circulation of the eastern tropical Pacific: A review. Progr. Oceanogr., 69: 181-217.

Legeckis, R. 1986. A satellite time series of sea surface temperatures in the eastern equatorial Pacific Ocean, 1982-1986. J. Geophys. Res., 91 (C11): 12879-12886.

López-Victoria, M. and D.M. Rozo. 2006. Model-based geomorphology of Malpelo island and spatial distribution of breeding seabirds. Bol. Invest. Mar. Cost., 35: 111-131. 
Manly, B. and J.A. Navarro. 2016. Multivariate statistical methods. A primer. $4^{\text {th }}$ ed. Chapman-Hall, London, 253 p.

Metoceanica. 2017. Caracterización preliminar de la circulación oceánica estacional en la zona de influencia del parque Santuario de Fauna y Flora Malpelo usando modelos numéricos oceánicos. Metoceanica Colombia SAS. 39 p.

Ministerio del Medio Ambiente. 1995. Resolución 1292 de 1995 por la cual se alinda y declara el Santuario de Fauna y Flora Malpelo. Bogotá, D.C. 3 p.

Ministerio de Ambiente y Desarrollo Sostenible. 2017. Resolución 1907 de 2017 por medio de la cual se reserva, delimita, alindera y declara como parte del Santuario de Fauna y Flora Malpelo un área ubicada en la región central de la cuenca Pacífica colombiana. Bogotá, D.C. 16p.

Parques Nacionales Naturales. 2015. Plan de manejo del Santuario de Fauna y Flora Malpelo. Malpelo punta de lanza del Pacífico colombiano. Cali, 163 p.

Ribeiro, P. and P. J. Diggie. 2018. Package 'geoR'. Version 1.7-5.2.1.

Rodríguez-Rubio, E., and J. Stuardo. 2002. Variability of photosynthetic pigments in the Colombian Pacific Ocean and its relationship with the wind field using ADEOS-I data. J. Earth Syst. Sci., 111: 227-236. doi:10.1007/BF02701969

Rodríguez-Rubio, R. y A. Giraldo. 2011. Características oceanográficas en la isla Malpelo y su relación con la cuenca oceánica del Pacífico colombiano. Bol. Invest. Mar. Cost., 40 (Supl. Esp.): 19-32.

Rodríguez-Rubio, E., J. Ortiz and J. Rueda. 2007. Aspectos oceanográficos. En: DIMAR-CCCP y UAESPNNDTSO. Santuario de Fauna y Flora Malpelo: descubrimiento en marcha, (Ed.) DIMAR, Bogotá, pp. 29-44.

Statsoft. 2007. STATISTICA (data analysis software system), version 8. www.statsoft.com.Warrick, A.W., D.E. Myers and D. R. Nielsen. 1986. Geostatistical Methods Applied to Soil Science. Methods of Soil Analysis. Part 1. Physical and Mineralogical Methods- Agronomy Monograph, 9: 53-81.

Werdell, P. J., B.A. Franz, S.W. Bailey, G.C. Feldman, E. Boss, V.E. Brando, et al. 2013. Generalized ocean color inversion model for retrieving marine inherent optical properties. Appl. Opt., 52: 2019-2037. doi:10.1364/AO.52.002019

RECIBIDO/RECEIVED: 22/08/2020

ACEPTADO/ACCEPTED: 30/06/2021 